\title{
ALTERAÇÕES QUÍMICAS E NUTRICIONAIS DO GRÃO-DE-BICO (Cicer arietinum L.) CRU IRRADIADO E SUBMETIDO A COCÇÃO
}

\section{Andrea Cristina Penati Ferreira}

Nutricionista

Orientador: Profa. Dra. SOLANGE GUIDOLIN CANNIATTI BRAZACA

Dissertação apresentada à Escola Superior de Agricultura "Luiz de Queiroz", Universidade de São Paulo, para obtenção do título de Mestre em Ciências, Área de Concentração: Ciência e Tecnologia de Alimentos.

PIRACICABA

Estado de São Paulo - Brasil

Agosto- 2004 


\section{ERRATA}

ANDREA CRISTINA PENATI FERREIRA - ALTERAÇÕES QUÍMICAS E NUTRICIONAIS DO GRÃO-DE-BICO (Cicer arietinum L.) CRU E SUBMETIDO A COCÇÃO

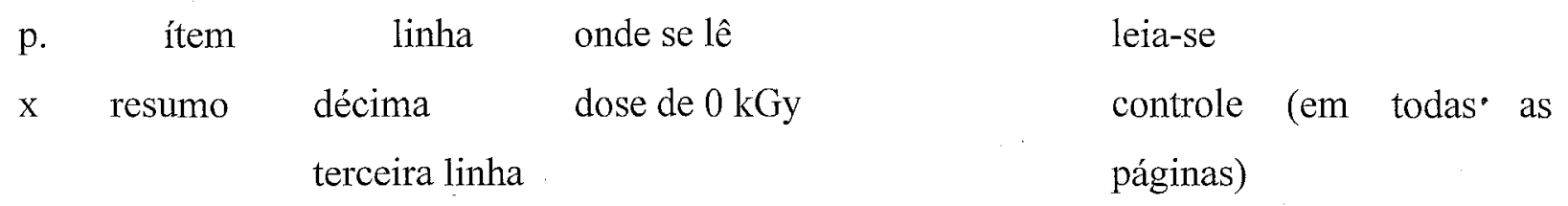

$204.1 \quad$ primeira linha proteina $(\mathrm{b} ; \mathrm{a})$; fibras dietéticas proteina $(\mathrm{a} ; \mathrm{a}) ; \quad$ fibras (a;a) dietéticas $(b ; a)$

27 trigéssima $4.3 \quad$.. digestibilidade da proteína $\ldots$ digestibilidade $\mathrm{da}$ primeira linha nas doses 0,2 e $4 \mathrm{kGy} \ldots \quad$ proteína nas doses 2 e 4 $\mathrm{kGy} \ldots$

$30 \quad 4.4$ décima $\quad \ldots$ dialise de ferro nas doses $0,2 \ldots$ dialise de ferro no primeira linha e $4 \mathrm{kGy} \quad$ controle e na dose $2 \mathrm{kGy}$

405 segunda linha na composição centesimal após considerando o efeito da a cocção... $\quad$ cocção....

405 sexta linha os tratamentos não promoveram a irradiação e cocção não alterações no teores de promoveram alterações no aminoácidos a ponto de ser teores de aminoácidos em importante para que seja relação ao grão cru. Porém instalada.... não a ponto de ser importante para que seja considerada como causa de 
Dados Internacionais de Catalogação na Publicação (CIP) DIVISÃO DE BIBLIOTECA E DOCUMENTAÇÃO - ESALQIUSP

Ferreira, Andrea Cristina Penati

Alterações quimicas e nutricionais do grão-de-bico (Cicer arietinum L.) cru irradiado e submetido a cocção / Andréa Cristina Penati Ferreira. - - Piracicaba, 2004.

$47 p$.

Dissertação (mestrado) - - Escola Superior de Agricultura Luiz de Queiroz, 2004.

Bibliografia.

1. Alimento cozido 2. Análise de alimentos 3: Composição de alimentos 4. Grão-debico 5 . Irradiação de alimentos I. Título

CDD 641.35657

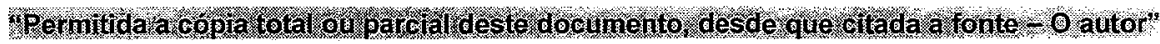


À minha mãe Maria Irene minha eterna gratidão e amor, Ao meu marido Flávio pelo apoio, incentivo, compreensão e paciência

A minha filha Gabriela, minha jóia mais rara, pela familia que somos

DEDICO. 


\section{AGRADECIMENTOS}

A todas as pessoas que, direta ou indiretamente, colaboraram para realização deste trabalho.

À Profa. Dra. Solange Guidolin Canniatti Brazaca, pela amizade, oportunidade, incentivo, paciência e orientação na realização deste trabalho.

À Técnica de Laboratório Maria de Lourdes Perin Storer, pela colaboração e execução das análises.

Ao Instituto de Tecnologia de Alimentos (ITAL), pela contribuição nas análises de aminoácidos.

Aos colegas do Curso de Pós-Graduação, pelo incentivo e amizade durante estes anos. 


\section{SUMÁRIO}

Página

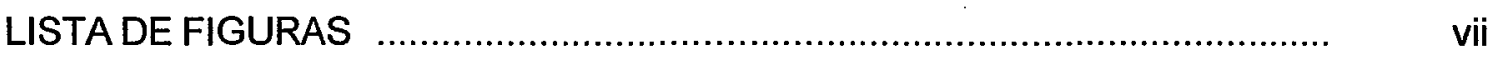

LISTA DE QUADROS …...................................................................... viii

LISTA DE TABELAS ......................................................................... ix

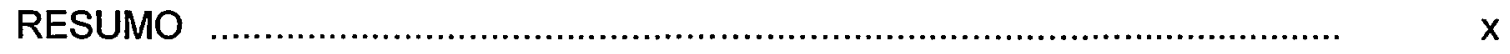

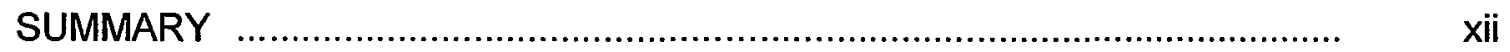

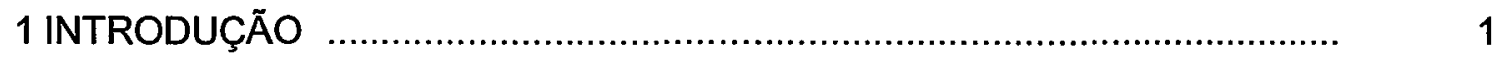

2 REVISÃO DE LITERATURA ….............................................................. 3

2.1 Caracteristicas agronômicas ............................................................... 3

2.2 Composição quimica e aspectos nutricionais .......................................... 3

2.3 Consumo e produção ........................................................................

2.4 Fatores antinutricionais .................................................................

2.5 Irradiação de alimentos ......................................................................... 7

2.6 Utilização das radiações ionizantes na conservação …............................. 8

2.7 Sensibilidade dos nutrientes à irradiação ............................................... 9

2.8 Irradiação de Leguminosas ................................................................. 10

2.9 Comparações da irradiação com outros métodos de conservação $\quad$............ 11

2.10 Embalagem para produtos irradiados ................................................. 13

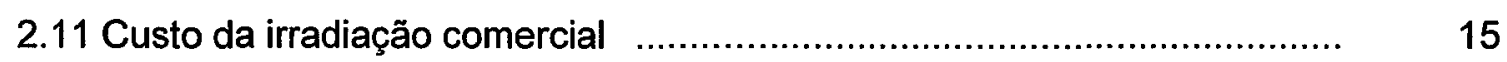

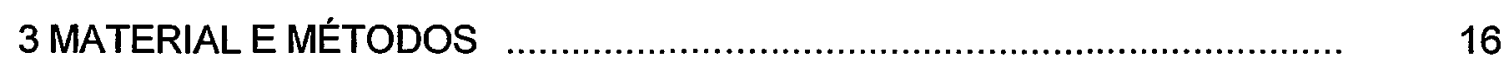

3.1 Materia-prima ................................................................................ 16

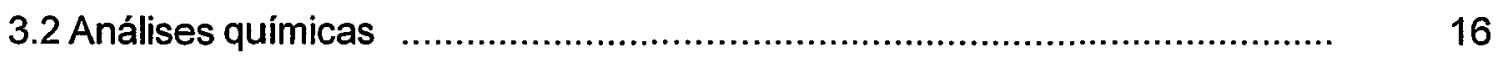

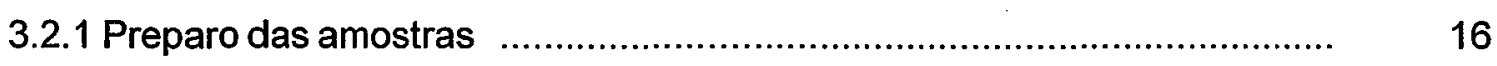

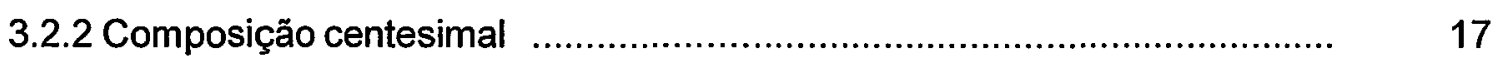

3.2.3 Composição mineral ........................................................................ 17 
3.2.4 Digestibilidade da proteína "in vitro" ..................................................... 18

3.2.5 Perfil de aminoácido .................................................................... 18

3.2.6 Disponibilidade de ferro "in vitro" ........................................................ 19

3.3 Análise estatística ................................................................................. 19

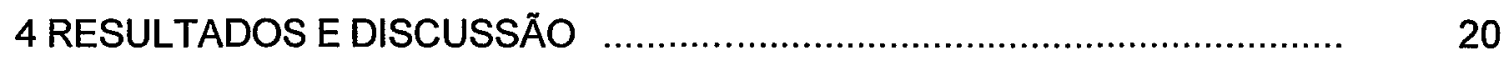

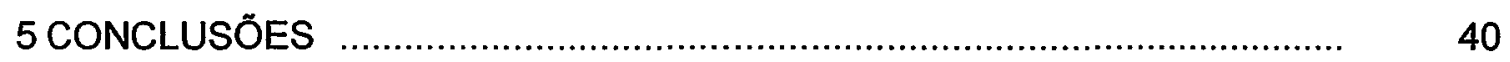

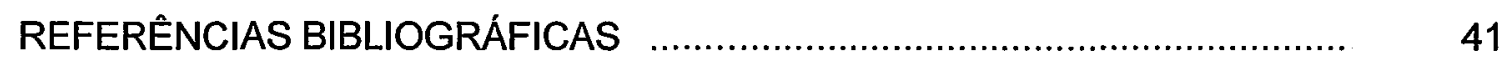




\section{LISTA DE FIGURAS}

Página

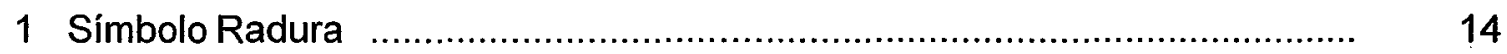

2 Composição centesimal $(\mathrm{g} / 100 \mathrm{~g})$ das amostras de grão-de-bico cruas e cozidas expressos na base seca ........................................................ 20

3 Composição mineral em $\mathrm{mg} / 100 \mathrm{~g}$ nas amostras de grão de bico cru e cozido expressos na base seca .......................................................... 23

4 Digestibilidade da proteína "in vitro" do grão-de-bico irradiados nas doses de radiação $0,2,4,6$, 8 e $10 \mathrm{kGy}$

5 Porcentagem de ferro dialisável "in vitro" de grão-de-bico cru e cozido nas doses de radiação de $0,2,4,6,8$ e $10 \mathrm{kGy}$ 


\section{LISTA DE QUADROS}

Página

1 Processos combinados de conservação de alimentos

2 Valores de referência g/100g para a composição centesimal do grão-debico cru e cozido de acordo com o Instituto Brasileiro de Geografia e Estatísticas (1996), Tabela de Composição de Alimentos (2001), Latinfoods (2000) e USDA (2004), base seca

3 Valores de referência $\mathrm{mg} / 100 \mathrm{~g}$ para a composição mineral do grão-de-bico cru e cozido de acordo com o USDA (2004), base seca

4 "Score" de aminoácidos (\%) nas amostras de grão-de-bico cru, nas doses de radiação 0,6 e $10 \mathrm{kGy}$ comparado com as necessidades de aminoácidos essenciais em humanos

5 "Score" de aminoácidos (\%) nas amostras de grão-de-bico cozido, nas doses de radiação 0,6 e 10kGy comparado com as necessidades de aminoácidos essenciais em humanos 


\section{LISTA DE TABELAS}

Página

1 Composição em $\mathrm{mg}$ de aminoácidos $/ 100 \mathrm{mg}$ proteina na amostra irradiada de grão-de-bico cru nas doses de radiação de 0,6 , e 10kGy

2 Composição em $\mathrm{mg}$ de aminoácidos $/ 100 \mathrm{mg}$ proteina na amostra irradiada de grão-de-bico cozido nas doses de radiação de 0,6 , e $10 \mathrm{kGy}$

3 Composição em $\mathrm{mg}$ de aminoácidos $/ 100 \mathrm{mg}$ proteína na amostra irradiada de grão-de-bico cru e cozido na dose de radiação de OkGy

4 Composição em $\mathrm{mg}$ de aminoácidos/100 $\mathrm{mg}$ proteína na amostra irradiada de grão-de-bico cru e cozido na dose de radiação de $6 \mathrm{kGy}$

5 Composição em mg de aminoácidos $/ 100 \mathrm{mg}$ proteína na amostra irradiada de grão-de-bico cru e cozido na dose de radiação de $10 \mathrm{kGy}$ 


\title{
ALTERAÇÕES QUÍMICAS E NUTRICIONAIS DO GRÃO-DE-BICO (Cicer arietinum L.) CRU IRRADIADO E SUBMETIDO A COCÇÃO
}

\author{
Autora: ANDREA CRISTINA PENATI FERREIRA \\ Orientador: Profa. Dra. SOLANGE GUIDOLIN CANNIATTI BRAZACA
}

\section{RESUMO}

O grão-de-bico é uma leguminosa fonte de proteínas, carboidratos, minerais, vitaminas, fibras, apresenta baixo teor de substâncias antinutricionais, além de alta disponibilidade de ferro. Ainda é pouco consumido no Brasil, porém devido as suas características nutricionais pode ter o seu consumo aumentado. Como as demais leguminosas o grão-de-bico pode sofrer ataque de pragas e insetos. Para minimizar os efeitos causados pela estocagem a radiação gama tem se mostrado como uma boa alternativa. O presente trabalho teve por objetivos analisar a composição centesimal e mineral dos grãos crus e cozidos e verificar as alterações provocadas pela irradiação e pela cocção. A análise da composição centesimal e mineral foi realizada com a finalidade de verificar as alterações provocadas pela cocção nas características nutricionais do grão. Foi realizada também a análise da disponibilidade de ferro "in vitro", digestibilidade da proteína "in vitro" e perfil de aminoácidos nos grãos crus e cozidos irradiados (doses de 0, 2, 4, 6, 8 e $10 \mathrm{kGy}$ ) sendo a taxa de dose utilizada de $0,9696 \mathrm{kGy} / \mathrm{h}$. Estes parâmetros foram avaliados com a finalidade de verificar as alterações provocadas pela radiação gama proveniente do Cobalto-60 e cocção. Os dados obtidos foram analisados estatisticamente (Tukey $5 \%$ ), pelo programa SAS. Os resultados encontrados nas análises dos minerais demonstraram que apesar de ter ocorrido diminuição no conteúdo total destes elementos após a cocção, o grão-de-bico 
é excelente fonte de ferro, fósforo, potássio, magnésio, sódio, manganês, cálcio, cobre e zinco. A cocção aumentou todos os itens da composição centesimal com exceção dos carboidratos disponiveis, obtendo os seguintes valores: proteina $25,73 \%$ e $26,48 \%$, gordura $4,71 \%$ e $6,68 \%$, carboidratos $66,18 \%$ e $63,56 \%$ e fibras $20,42 \%$ e $24,67 \%$, respectivamente para os grãos crus e cozidos. Comparando-se os tratamentos (grãos crus e cozidos irradiados) pode-se observar que nas doses de 0,4 e 6 kGy a cocção não influenciou na digestibilidade da proteina, mas nos tratamentos que receberam doses de radiação de 2,8 e $10 \mathrm{kGy}$ houve influencia neste parâmetro, sendo que o grão-de-bico cozido apresentou melhor digestibilidade em doses maiores de radiação, embora os tratamentos tenham apresentado digestibilidade baixa. Observou-se que 0 grão-de-bico cru apresentou melhor diálise de ferro nas doses 0,2 e 4 kGy e o grãode-bico cozido apresentou melhora conforme o aumento da dose de radiação. Em relação aos aminoácidos essenciais o grão-de-bico apresentou valor nutricional adequado, de acordo com a FAO, exceto para metionina, como esperado, pois este é o principal limitante para as leguminosas e não foi devido aos tratamentos empregados que houve a deficiência. $O$ conteúdo de total de aminoácidos não sofreu variação, tanto para o cru como o cozido, em relação as doses de radiação. A irradiação constitui-se em um método de conservação inócuo em relação à provável perda de nutrientes, é um método que deverá ser utilizado futuramente, pois seus custos não são onerosos quando comparados a outros métodos tradicionais 


\title{
NUTRITIONAL AND CHEMICAL ALTERATION OF RAW, IRRADIATED AND COOKED CHICKPEA (CICER ARIETINUM L.)
}

\author{
Author: ANDREA CRISTINA PENATI FERREIRA \\ Adviser: Profa. Dra. SOLANGE GUIDOLIN CANNIATTI BRAZACA
}

\section{SUMMARY}

The chickpea is a legume font of proteins, carbohydrates, minerals, vitamins, fibers, with low content of antinutritive substances, besides the high availability of iron. It is still little consumed in Brazil, however, due to its nutritional characteristics, it might have its consumption increased. Like other legume, the chickpea might be attacked by plagues and insects. To minimize the effect caused by the storage, the gamma radiation has been proved to be a good alternative. The present work aimed at analyzing the centesimal and mineral composition of the raw and cooked seeds as well as verifying the alterations caused by the radiation and cooking processes. The analysis of the centesimal and mineral composition has been carried out with the objective of verifying the alterations on the nutritional characteristics of the seed caused by the cooking process. Also were carried out analysis of the availability of iron "in vitro", digestibility of the protein "in vitro" and the profile of amino acids in the raw and cooked irradiated seeds (doses of $0,2,4,6,8$ and $10 \mathrm{kGy}$ ) being the used dose rate of 0,9696 kGy/h. These parameters have been evaluated with the objective of verifying the alterations caused by the gamma radiation from the Cobalt- 60 and the cooking process. The data obtained have been statistically analyzed (Tukey $5 \%$ ) by the SAS program. The results 
of the mineral analysis showed that despite the decrease on the total contents of these elements after the cooking, the chickpea is an excellent font of iron, phosphorus, potassium, magnesium, sodium, manganese, calcium, copper and zinc. The cooking process increased all the items of the centesimal composition except for the carbohydrates available, obtaining the following values: protein $25.73 \%$ and $26.48 \%$, fat $4.71 \%$ and $6.68 \%$, carbohydrates $66,18 \%$ and $63.56 \%$, and fibers $20.42 \%$ and $26.67 \%$, for the raw and the cooked seeds respectively. Comparing the treatments (irradiated raw and cooked seeds), it is possible to observe that in the doses of 0, 4 and $6 \mathrm{kGy}$ the cooking hasn't influenced the digestibility of the protein, but the treatments that received radiation doses of 2,8 and $10 \mathrm{kGy}$ were influenced in these parameters. The cooked chickpea has shown better digestibility in higher doses of radiation although the treatments have shown low digestibility. It has been observed that the raw chickpea presented a better dialysis of iron in the doses 0,2 and $4 \mathrm{kGy}$ and the cooked chickpea presented improvement according to the increase of radiation doses. In relation to the essential amino acids, the chickpea has presented an adequate nutritional value, according to the FAO, except for the methionine - as expected - for this is the main restriction for the legume and the deficiency was not due to the treatments given. The content of the total amino acids have not suffered variation - both for the raw and cooked seeds - in relation to the radiation doses. The irradiation is constituted of an innocuous conservation method in relation to the probable nutrient loss, it is a method that might be used in the future, for its costs are not expensive when compared to other traditional methods. 


\section{INTRODUÇÃO}

O aumento das necessidades mundiais de alimentos e os problemas advindos da demanda de estruturas adequadas de armazenagem e processamento nos levam buscar novos métodos de preservação. Uma alternativa é a utilização da radiação ionizante, com o propósito de preservar e desinfestar grãos. É utilizada também para estender a vida de prateleira e reduzir perdas das safras, durante a armazenagem do produto. A irradiação é utilizada como um método de preservação dos alimentos, tanto "in natura" quanto processados industrialmente (Villavicencio, 1998).

O consumo de leguminosas tem grande importância na nutrição humana, pois constituem fontes de proteínas, vitaminas e minerais. A suplementação de cereais com leguminosas ricas em proteinas é considerado a melhor solução para a desnutrição protéico-calórica no mundo (Chitra et al., 1996).

A cultura do grão-de-bico ainda não se firmou no Brasil, sendo escassas as informações sobre os problemas que podem afetar seu desenvolvimento. $O$ consumo do grão-de-bico (Cicer arietinum L.) poderá ser aumentado pela divulgação de suas propriedades nutricionais. Pesquisas conduzidas no Instituto Agronômico de Campinas indicam que esta leguminosa poderá ser uma importante opção agrícola para o Estado de São Paulo (Almeida,1997).

O grão-de-bico é fonte de proteínas, carboidratos, minerais, vitaminas e fibras. Se destaca entre as leguminosas por sua digestibilidade, baixo teor de substâncias antinutricionais, além de apresentar a melhor disponibilidade de ferro. CanniattiBrazaca \& Silva (2004) pesquisando diversas leguminosas (feijão comum, feijão branco, feijão preto, ervilha, soja, lentilha e grão-de-bico) encontraram a melhor disponibilidade de ferro para o grão-de-bico.

Devido a escassez de informações sobre o grão-de-bico, e da necessidade de verificar as alteraçőes que ocorrem com diferentes processamentos, o presente projeto 
teve por objetivos:

- caracterizar o grão-de-bico, sendo realizada a composição centesimal e de minerais em grão crus e cozidos não irradiados com o propósito de verificar os efeitos da cocção; - avaliar o efeito das diferentes doses de radiação gama do Cobalto-60 sobre a disponibilidade de ferro "in vitro", a digestibilidade protéica "in vitro" e o perfil de aminoácidos do grão-de-bico cru e cozido visando o impacto deste processo nesta leguminosa. 


\section{REVISÃO DE LITERATURA}

\subsection{Característica agronômicas do grão-de-bico}

O grão-de-bico pertence à família Leguminasae, sub-família Papilionoideae. O gênero Cicer compreende muitas espécies, mas a Cicer arietinum L. é mais cultivada e consumida (Braga, 1997).

Segundo Muehlbauer (1996) o grão-de-bico é conhecido no mundo como: "bengal gram" (Índia), "chickpea" (Estados Unidos), "garbanzo" (América Latina), "hommes, hamaz" (Mundo Árabe), "nohud, labladi" (Turquia) e "shimbra" (Etiópia).

As sementes podem apresentar caracteristicas diferentes que classificam os grãos em dois grupos: o "desi", apresentando sementes pequenas, e o "kabuli", apresenta sementes maiores (Chavan et al., 1988). O grupo "desi" representa a maior parte da produção mundial segundo dados da FAO (2001), sendo que de acordo com Braga et al (1992) o grão-de-bico consumido no Brasil é na sua totalidade do tipo "kabuli".

\subsection{Composição química $e$ aspectos nutricionais}

As leguminosas representam talvez o papel mais importante na alimentação universal, são de suma importância na alimentação do nosso país, oferecendo proteínas de limitado valor biológico (Ornellas,1995). As proteínas desta leguminosa apresentam deficiência de metionina e cistina, teores satisfatórios de triptofano e treonina, e altos teores dos demais aminoácidos essenciais. A proteína do grão-de-bico contém lisina em quantidades semelhantes a da proteína da soja. A adição de metionina ao grão-de-bico pode melhorar seu valor nutritivo (Avancini et al, 1992). 
O grão-de-bico apresenta a seguinte composição química por 100 gramas de produto "in natura": 364 calorias; $61,1 \mathrm{~g}$ de glicidios; $18,2 \mathrm{~g}$ de proteínas; $6,2 \mathrm{~g}$ de lipídios; $134 \mathrm{mg}$ de cálcio; $324 \mathrm{mg}$ de fósforo; $7,3 \mathrm{mg}$ de ferro; $3,4 \mathrm{~g}$ de fibra; $3,0 \mathrm{~g}$ de cinza e $11,5 \mathrm{~g}$ de umidade. A composição de aminoácidos por grama de nitrogênio é de: $428 \mathrm{mg}$ de lisina; $139 \mathrm{mg}$ de metionina/cistina; $235 \mathrm{mg}$ de treonina e $54 \mathrm{mg}$ de triptofano (IBGE, 1996).

De acordo com Franco (1997) o grão-de-bico apresenta: $5 \mu \mathrm{g}$ de retinol; $460 \mu \mathrm{g}$ de tiamina; $160 \mu \mathrm{g}$ de riboflavina; $1,700 \mathrm{mg}$ de niacina; $4,9 \mathrm{mg}$ de ácido ascórbico; 129,8 mg de sódio; $971,3 \mathrm{mg}$ de potássio.

Segundo a Tabela Brasileira de Composição de Alimentos (USP, 2001) o grãode-bico apresenta a seguinte composição química por 100 gramas de produto "in natura": 295 calorias; $62,4 \mathrm{~g}$ de glicídios; $16,8 \mathrm{~g}$ de proteinas; $6,8 \mathrm{~g}$ de lipídios e $20,72 \mathrm{~g}$ de fibra alimentar e, apresenta a seguinte composição química por 100 gramas de produto cozido: 97 calorias; $21,26 \mathrm{~g}$ de glicídios; $6,60 \mathrm{~g}$ de proteínas; $1,58 \mathrm{~g}$ de lipídios e $7,05 \mathrm{~g}$ de fibra alimentar.

O grão-de-bico é excelente fonte de carboidratos e de proteinas, que abrangem cerca de $80 \%$ do peso total das sementes secas. O conteúdo total de carboidratos das sementes varia de 52,5 a $70,9 \%$ sendo o amido o principal componente dos carboidratos, cujo conteúdo, nas sementes integrais, é de 41,0 a 50,8\% (Braga, 1997).

Em função das características de seus carboidratos o grão-de-bico foi indicado para dietas de pessoas com problemas de diabetes, sendo associado à redução dos níveis de glicose plasmáticos (Dilawari et al., 1981).

O grão-de-bico se destaca também dentre as outras leguminosas por seu conteúdo protéico e de aminoácidos (Braga, 1997). De acordo com Tavano (2002) a proteina do grão-de-bico tem sido considerada de melhor valor nutricional dentre as leguminosas.

O conteúdo de proteína bruta das sementes de grão-de-bico varia na maioria das vezes, entre 17 e $24 \%$, podendo atingir valores extremos de 12,4 a 31,5\% (Dilawari et al., 1981).

Diversos fatores afetam o conteúdo protéico das sementes, desde os ambientais, durante o crescimento, até diferentes práticas culturais. $O$ uso de 
reguladores de crescimento, de nitrogênio, fósforo e enxofre melhoram os niveis de proteína e de aminoácidos essenciais, inclusive os sulfurados (Braga, 1997).

Um dos aspectos relativos ao valor nutricional de uma proteína é seu perfil de aminoácidos. As leguminosas em geral são conhecidas por apresentarem deficiência no teor de aminoácidos sulfurados. O grão-de-bico apresenta como primeiro aminoácido limitante os sulfurados, seguido do triptofano (Tavano, 2002).

Apesar da deficiência de aminoácidos, a proteína apresenta uma boa digestibilidade, na faixa de 79 a $92 \%$ (Birender et al. ${ }^{1}, 1987$; 1984; Singh ${ }^{2}, 1985$ ), citados por Avancini et al. (1992) e Rossi et al.(1984) respectivamente.

Quanto a outros aminoácidos essenciais não são comuns citações quanto à deficiência. No caso da lisina, é conhecido seu alto teor na proteína do grão-de-bico (Dodok et al., 1993).

Singh \& Jambunatam (1981) utilizando o método de digestão por sequência de pepsina/pancreatina e determinação do grau de hidrólise pelo método de Kjeldahl, encontrou percentuais de digestibilidade da proteína de 72,7 a $79,1 \%$ entre sete cultivares de grão-de-bico do tipo "kabuli" e 63,7 a $76 \%$ entre oito cultivares do tipo "desi".

Queiroz et al. (2002) observaram que o teor protéico das leguminosas cruas liofilizadas: ervilha (Pisum sativum), feijão-comum (Phaseulus vulgaris), grão-de-bico (Cicer arietinum) e lentilha (Lens culinaris), não diferem quanto ao teor protéico do grãode-bico.

De acordo com Braga (1997) essas sementes apresentam considerável quantidade de óleo, cujos valores variam de 3,8 a $10,2 \%$. Seu óleo possui alto teor de ácidos graxos insaturados, particularmente linoléico e oleico. O efeito redutor do colesterol pelo grão-de-bico se deve ao conteúdo de ácidos graxos essenciais presentes na semente, particularmente linoléico e linolênico, sendo uma das leguminosas alimentícias com menor teor de ácidos graxos saturados. Esse mesmo autor também relata que os triglicérides e os fosfolipídeos foram os componentes predominantes nos lipídios do grão-de-bico.

\footnotetext{
${ }^{1}$ BIRENDER, K.; SONI, G.L.; SINGH, R. Nutricional evaluation of gram (Cicer arietinum) varieties. Human Nutricion. Food Sciences and Nutrition, v.41F, n.2, p.121-128, 1997.

${ }^{2} \mathrm{SINGH}$, U. Nutritional quality of chickpea (Cicer arietinum L.) current status and future reserch needs. Qualitas Plantarum Plant Foods for Human Nutrition, v.35, n.4, p.339-351, 1985.
} 
Queiroz et al (2002), observaram a composição centesimal em leguminosas cruas liofilizada: ervilha (Pisum sativum), feijão-comum (Phaseulus vulgaris), grão-debico (Cicer arietinum) e lentilha (Lens culinaris), verificaram que o grão-de-bico apresentou teor de lipídeos totais aproximadamente três vezes maior que das demais leguminosas. O teor de fibra é importante constituinte do grão-de-bico e está relacionado com o teor de tegumento das sementes. Entretanto, o grão-de-bico também é importante fonte de minerais e vitaminas. De acordo com Avancini et al. (1992) o grão-de-bico é uma boa fonte de minerais ( $\mathrm{P}, \mathrm{Mg}, \mathrm{Fe}, \mathrm{K}, \mathrm{Co}, \mathrm{Mn})$ e também apresenta quantidades significativas de vitaminas do complexo $B$.

O cálcio e o ferro são nutrientes, em geral, deficientes nas dietas da população de baixa renda, especialmente das crianças na idade pré-escolar, mulheres grávidas e lactentes. Uma vez que o tegumento contribui com cerca de $70 \%$ do total de cálcio das sementes de grão-de-bico, o consumo de sementes integrais é desejável quando há deficiência de cálcio. O grão-de-bico é relativamente rico em vitamina $C \mathrm{em}$ comparação com outras leguminosas, porém não é fonte dessa vitamina (Braga,1997).

\subsection{Consumo e produção}

A cultura do grão-de-bico ainda não se firmou no Brasil, sendo escassas as informações sobre os problemas que podem afetar seu desenvolvimento (Almeida,1997).

O Brasil consome, anualmente, cerca de 2000 toneladas de grão-de-bico, provenientes principalmente do México e do Chile. Este consumo poderá ser aumentado pela divulgação de suas propriedades nutricionais e culinárias. Pesquisas conduzidas no Instituto Agronômico de Campinas indicam que esta leguminosa poderá ser uma importante opção agrícola para o Estado de São Paulo, para ser semeada no periodo de fevereiro-abril (Avancini et al., 1992). No Estado de São Paulo, segundo Braga (1998), trabalhos de pesquisas com grão-de-bico vêm se intensificando e visam, sobretudo, a avaliação de genótipos para seleção dos mais adequados às condições paulistas de cultivo, uma vez que a cultura do grão-de-bico inexiste comercialmente no Brasil. 
O potencial de rendimento do grão-de-bico pode ultrapassar 4 t/ha, embora os rendimentos efetivamente obtidos pelos agricultores sejam bem inferiores. Os paises produtores giram em torno de 40 , sendo o principal produtor a Índia (Braga, 1997)

Segundo a FAO (2001) o consumo do grão-de-bico ainda muito limitado no Brasil, quando comparado a outras leguminosas como o feijão. $O$ grão de bico é uma leguminosa que nutricionalmente tem grande potencial e deve ser explorado para que possa minimizar as deficiências protéicas e minerais da população.

\subsection{Fatores antinutricionais}

Assim como outras leguminosas, o grão-de-bico, quando cru, apresenta componentes que podem ser considerados causadores de prejuízos nutricionais, tanto por afetarem diretamente a utilização de certos nutrientes como pela sensação de mal estar gerada no organismo, inibindo seu consumo. Dentre outros, destacam-se: inibidores de proteases que prejudicam a ação das enzimas tripsina e quimotripsina; inibidores de $\alpha$-amilase que prejudicam a ação da amilase pancreática levando a prejuizos na digestibilidade do amido da dieta; oligossacarideos, relacionados com a produção de flatulência em homens e animais. No entanto, segundo Tavano (2002) este conjunto de fatores é inativado pelo aquecimento. Para a alimentação humana não há preocupação já este não é consumido cru.

Embora os fatores antinutricionais devam ser cogitados em qualquer leguminosa de grão, sua importância é minimizada no grão-de-bico, exceto os fatores promotores da flatulência, que devem ser destacados nesta leguminosa em decorrência dos teores de oligossacarídeos nela presentes. Recentes estudos também relatam que o amido e a hemicelulose contribuem para a flatulência causada pelo grão-de-bico (Braga, 1997).

\subsection{Irradiação de alimentos}

De acordo com o Centro de Energia Nuclear na Agricultura (CENA) (2003), os alimentos irradiados podem ter sua vida útil ou de prateleira prolongada. Em geral, o processo de irradiação acarreta mínimas alterações químicas nos alimentos. Nenhuma das alterações conhecidas são nocivas ou perigosas; motivo pelo qual a Organização Mundial da Saúde (OMS) recomenda a aplicação e o uso da irradiação de alimentos. 
A irradiação de alimentos é um excelente método de conservação, bem como um coadjuvante para reforçar a ação de outros processos aplicados com a mesma finalidade. A irradiação satisfaz plenamente os objetivos de proporcionar aos alimentos estabilidade nutritiva, condições de sanidade e de longo periodo de armazenamento (Embrarad, 2002).

De acordo com Villavicencio (1998) a irradiação de alimentos é um tratamento que consiste em submeter os alimentos, já embalados ou a granel, a uma quantidade minuciosamente controlada de radiação ionizante, por um tempo prefixado, com objetivos bem determinados. O processo não aumenta o nivel de radioatividade normal dos alimentos, podem ser utilizadas nos alimentos irradiações ionizantes, em geral, cuja energia seja inferior ao limiar das reações nucleares que poderiam induzir radiotividade no material irradiado.

É importante salientar que tanto a radiação gama de ${ }^{60} \mathrm{Co}$, como a dos feixes de elétrons dos aceleradores, não tem energia suficiente para provocar qualquer reação nuclear na matéria e, portanto, não deixam nenhum resíduo radioativo no material após a irradiação (Singh, 1985).

\subsection{Utilização das radiações ionizantes na conservação}

Segundo Villavicencio (1998) grandes perdas de grãos ocorrem devido a infestação por insetos durante o armazenamento. Os alimentos frescos, de origem vegetal ou animal separados de suas fontes naturais não perecem de imediato e sim vão lentamente se modificando e passam da vida latente para um estado de menor ou maior deterioração. Conservá-los é saber deter os processos de deterioração, alterando as condições do meio que a favorecem (Ornellas, 1995).

As radiações gama oriundas dos radioisótopos (Cobalto 60 e Césio 137) são utilizadas com fim bactericida. O Comitê Misto de Especialista FAO/ OIEA/ OMS, reunido em 1974 em Viena, estabeleceu que, para doses de até 5 kGy (500 krads) os dados referentes a efeitos químicos de radiações baseados na experimentação alimentar animal permitem indicar que os alimentos assim tratados são aptos para o consumo humano (Ornellas, 1995). 
A irradiação é um processo pós-colheita, ela não pode substituir os agrotóxicos utilizados no campo, mas pode substituir o uso dos aditivos e produtos químicos usados em alimentos como o brometo de metila, cujo uso está condenado (CENA, 2003).

De acordo com Centro de Energia Nuclear na Agricultura (2003) a grande vantagem das radiações ionizantes é a de esterilizar alimentos dentro de qualquer tipo de embalagem sem danificá-la e sem aumentar a temperatura. Os principais processos de irradiação de alimentos, podem ser reunidos em três grupos:

1) Radurização - usa doses baixas (de 0,5 a $1,0 \mathrm{kGy}$ ) com fim de inibir o brotamento (batata, alho, cebola), retardar o período de maturação e de deterioração de frutas e hortaliças, além de controlar os insetos que infestam grãos (trigo e feijão), frutas e hortaliças (gorgulhos e moscas-das-frutas)

2) Radiciação ou radiopasteurização - usa doses intermediárias (1 a 10 kGy) com o fim de pasteurizar sucos de frutas, retardar a deterioração de carnes frescas e controle de Salmonella em produtos avícolas.

3) Radapertização ou esterilização comercial - usa doses elevadas (de 10 a 70 kGy) na esterilização de carnes em geral, dietas e outros produtos processados.

\subsection{Sensibilidade dos nutrientes à irradiação}

Os macronutrientes, tais como as proteinas, os carboidratos e as gorduras são relativamente estáveis às doses de até $10 \mathrm{KGy}$, e os micronutrientes, principalmente as vitaminas podem ser sensíveis a qualquer método de tratamento de alimentos. A sensibilidade de diferentes tipos de vitaminas ao método de irradiação e a outros métodos de tratamento de alimentos é variada. Vitaminas $C$ e $B_{1}$ (tiamina) são mais sensíveis à irradiação, vitaminas lipossolúveis são parcialmente destruídas e os tocoferóis são particularmente mais sensiveis nas doses de pasteurização. Em geral, o processo de irradiação nas doses permitidas acarreta poucas alterações químicas nos alimentos. A qualidade nutricional do alimento não é mais afetada do que quando o alimento é tratado por outros métodos convencionais de conservação (Villavicencio, 1h998).

No Brasil o Decreto no. 72.718 de 29 de agosto de 1973, estabeleceu normas gerais sobre irradiação de alimentos e hoje temos a resolução RDC $n^{\circ} 21$ de 26 de 
janeiro de 2001 que estabeleceu que a dose mínima é aquela suficiente para alcançar finalidade pretendida e a dose máxima a ser empregada é aquela inferior a dose que comprometeu as propriedades funcionais e ou os atributos sensoriais do alimento (Anvisa, 2003).

\subsection{Irradiação de leguminosas}

Brigide (2002) estudando a disponibilidade de ferro em grão de feijão comum (Phaseolus vulgaris L.) irradiados, observou que o processo de irradiação com dose de $6 \mathrm{kGy}$ mostrou redução dos fatores antinutricionais em relação ao feijão cozido. A irradiação foi efetiva para a disponibilidade do ferro, com conseqüente melhora no valor nutritivo, além de conferir conservação prolongada do grão.

No estudo de Pinn (1992), o aumento da dose de radiação provocou diminuição do teor de taninos no feijão cozido (Phaseolus vulgaris L.), variedade carioca, irradiado nas doses de $2 ; 4 ; 6 ; 8 ; 10 ; 15$ e $20 \mathrm{kGy}$. O teor de taninos do controle foi de $0,47 \% \mathrm{mEq}$ de catequina e, com a dose de radiação $20 \mathrm{kGy}$, o teor apresentado foi de $0,29 \% \mathrm{mEq}$ de catequina.

A irradiação reduz perdas e mantêm a qualidade nutricional do feijão proporcionando maior vida útil $e$ melhoramento da qualidade tecnológica no processamento de alimentos irradiados (Ahmed, 1993).

Mancini-Filho (1990) observou reduções iguais ou superiores a $50 \%$ no tempo de cocção de feijões (Phaseolus vulgaris L.) das variedades catu e rajado irradiados com dose de 10kGy e armazenados por 9 e 10 meses .

Armelin (2003) estudando o efeito da radiaçăo gama nas doses de 0, 1, 2, 6 e 10 kGy na capacidade de hidratação e cocção de feijão comum (Phaseolus vulgaris $L$.) observou que a irradiação não influenciou no processo de hidratação e que apenas o grão não irradiado necessitou de maior tempo de cocção para se tornarem macios.

Kikuchi (1987) analisando o efeito de baixas doses de radiação (0, 0,5 e 2 Gy) sobre semente de feijão carioca, observou que com-a irradiação não houve estímulo ou inibição no desenvolvimento das sementes analisadas plantadas. 


\subsection{Comparações da irradiação com outros métodos de conservação}

De acordo com Villavicêncio (1998), em combinação com outros processos, como por exemplo, calor, baixa atividade de água, $\mathrm{pH}$, atmosfera modificada, salga, acidificação e embalagens, a irradiação pode oferecer produtos mais estáveis em condições tropicais. Os tratamentos quimicos e a radiação entre outros, oferecem vantagens sobre os tratamentos não combinados (Quadro 1) e incrementam os efeitos benéficos desta tecnologia. 


\begin{tabular}{|c|c|c|c|c|}
\hline Método & Fumigação & Refrigeração & Pasteurização & Irradiação \\
\hline & $\begin{array}{l}\text { Efetivo na } \\
\text { descontaminação } \\
\text { microbiana e } \\
\text { insetos em } \\
\text { alimentos secos }\end{array}$ & $\begin{array}{l}\text { Aplicável em } \\
\text { alimentos } \\
\text { liquidos e } \\
\text { sólidos }\end{array}$ & $\begin{array}{l}\text { Aplicável } \\
\text { somente em } \\
\text { alimentos } \\
\text { sólidos }\end{array}$ & $\begin{array}{l}\text { Aplicável em } \\
\text { alimentos } \\
\text { sólidos. Efetivo } \\
\text { na inativação de } \\
\text { patogênos em } \\
\text { alimentos } \\
\text { congelados }\end{array}$ \\
\hline Limitações & $\begin{array}{l}\text { Resíduos, } \\
\text { resistência dos } \\
\text { insetos, } \\
\text { problemas } \\
\text { ambientais e de } \\
\text { salubridade }\end{array}$ & $\begin{array}{l}\text { CFCs causam } \\
\text { problemas } \\
\text { ambientais; } \\
\text { não inativam } \\
\text { microrganismo } \\
\text { s patôgenos }\end{array}$ & $\begin{array}{l}\text { Geralmente não } \\
\text { aplicáveis a } \\
\text { alimentos } \\
\text { sólidos }\end{array}$ & $\begin{array}{l}\text { Não aplicável a } \\
\text { alimentos } \\
\text { liquidos, tem } \\
\text { problemas de } \\
\text { restrição de } \\
\text { regulamentação }\end{array}$ \\
\hline \multicolumn{5}{|l|}{ Alimentos } \\
\hline Especiarias & $\begin{array}{l}\text { Efetivo porém } \\
\text { causa problemas } \\
\text { ambientais e de } \\
\text { saúde coletiva }\end{array}$ & $\mathrm{N} / \mathrm{A}$ & Efetivo & $\begin{array}{l}\text { Altamente } \\
\text { efetivo }\end{array}$ \\
\hline $\begin{array}{ll}\text { Frutas } & e \\
\text { vegetais } & \end{array}$ & $\begin{array}{c}\text { Efetivo porém } \\
\text { causa problemas } \\
\text { ambientais e de } \\
\text { saúde coletiva }\end{array}$ & $\begin{array}{c}\text { Essencial para } \\
\text { manter a } \\
\text { qualidade }\end{array}$ & N/A & $\begin{array}{c}\text { Efetivo contra } \\
\text { infestação em } \\
\text { frutas frescas e } \\
\text { secas }\end{array}$ \\
\hline $\begin{array}{l}\text { Cereais } \quad \text { e } \\
\text { grão }\end{array}$ & $\begin{array}{l}\text { Efetivo porém } \\
\text { causa problemas } \\
\text { ambientais e de } \\
\text { saúde coletiva }\end{array}$ & N/A & $\mathrm{N} / \mathrm{A}$ & $\begin{array}{l}\text { Efetivo contra } \\
\text { infestação de } \\
\text { insetos }\end{array}$ \\
\hline $\begin{array}{l}\text { Raízes e } \\
\text { tuberculos }\end{array}$ & $\mathrm{N} / \mathrm{S}$ & $\begin{array}{c}\text { Efetivo contra } \\
\text { brotamento }\end{array}$ & N/A & Efetivo \\
\hline
\end{tabular}

Quadro 1 - Processos combinados de conservação de alimentos

Fonte: FAO et al. (1994)

N/A: não aplicável 
A irradiação de alimentos possui uma série de vantagens sobre os métodos tradicionais, por ser um processo a frio. Como a radiação tem elevado poder de penetração, o processo pode ser usado para tratar uma grande variedade de alimentos, numa considerável faixa de tamanhos e formas, com pouca ou nenhuma manipulação ou processamento, pode substituir os tratamentos químicos que deixam resíduos nos alimentos oferecendo um método efetivo para garantir ao consumidor proteção contra doenças transmitidas por alimentos (CENA, 2003).

\subsection{Embalagem para produtos irradiados}

Numa irradiação, onde não houver uma correta embalagem do produto, haverá uma reincidência de infestação e o processo se tornará inútil. $O$ material utilizado não deve interagir com os aditivos e/ou o produto embalado ou mesmo ser permeável, a resistência à radiação de vários materiais deve ser testada, porém atualmente com doses limites de até $10 \mathrm{kG}$ y para papel e papelão e $60 \mathrm{kGy}$ para material polimérico, é permitida pelo FDA para embalagens a serem irradiadas (Diehl, 1995)

A Diretoria Colegiada da Agência Nacional de Vigilância Sanitária (ANVISA) no uso da atribuição que the confere $o$ art. 11, inciso IV, do Regulamento aprovado pelo Decreto 3029, de 16 de abril de 1999, em reunião realizada em 24 de janeiro de 2001 e acordo com a Resolução RDC $n^{\circ} 21$, De 26 de janeiro de 2001 aprova que a embalagem deve ter condições higiênicas aceitáveis, ser apropriada para o procedimento de irradiação, estar de acordo com a legislação vigente e aprovada pela autoridade sanitária competente. Nos casos em que não estejam previstas em legislação nacional, as embalagens em contato direto com o alimento devem ser aquelas relacionadas pela Organização Mundial da Saúde, em documento próprio da OMS e submeter-se previamente aos critérios de inclusão de nova embalagem na legislação brasileira. Na rotulagem dos Alimentos Irradiados, além dos dizeres exigidos para os alimentos em geral e específico do alimento, deve constar no painel principal: "ALIMENTO TRATADO POR PROCESSO DE IRRADIAÇÃO", com as letras de tamanho não inferior a um terço $(1 / 3)$ do da letra de maior tamanho nos dizeres de rotulagem. Quando um produto irradiado é utilizado como ingrediente em outro 
alimento, deve declarar essa circunstância na lista de ingredientes, entre parênteses, após o nome do mesmo, assim como estar presente o símbolo internacional para alimentos irradiados conforme a Figura 1.

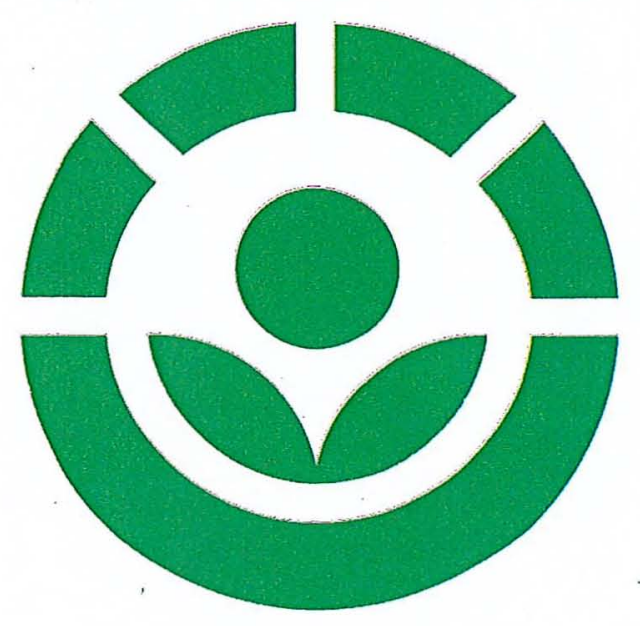

Figura 1 - Símbolo Radura

De acordo com o Decreto $n^{\circ} 72.718$, de 29 de agosto de 1973, de cada partida de alimento irradiado deverão ser retiradas amostras da mesma, de acordo com as instruções do órgão técnico específico, as quais serão colocadas à disposição das autoridades competentes, para a realização de análise fiscais em laboratório oficial. As amostras a que se refere este artigo serão acompanhadas de relatório firmado pela responsável pela operação de irradiação do alimento, no qual se indicará: a finalidade da irradiação; fonte energia e dose de irradiação e detalhes das condições ambientais reinantes durante a irradiação; descrição de qualquer tratamento a que tenha sido submetido o alimento antes, durante e após a irradiação; tipo e natureza da embalagem empregada para acondicionar o alimento irradiado; condições e período de armazenamento proposto para o alimento irradiado (ANVISA, 2003). 


\subsection{Custos da irradiação comercial}

Os custos estimados dos benefícios da irradiação comercial como um tratamento quarentenário, mostram que a irradiação pode ser competitiva com outros métodos de fumigação e outros tratamentos físicos, tais como calor e refrigeração (Nascimento, 1992). Os produtos tratados por irradiação não necessariamente têm seu preço aumentado. Segundo International Consultive Group on Food Irradiation (1999), estes custos são competitivos com 0 de outros tratamentos. A instalação de um irradiador de alimentos oscila entre um milhão a três milhões de dólares americanos. Como comparação, uma instalação para esterilizar leite, sucos de fruta e outros líquidos custa por volta de dois milhões de dólares. 


\section{MATERIAL E MÉTODOS}

O projeto foi desenvolvido no Laboratório de Bromatologia do Setor de Nutrição Humana e Alimento do Departamento de Agroindústria, Alimentos e Nutrição da Escola Superior de Agricultura "Luiz de Queiroz" da Universidade de São Paulo, em Piracicaba-SP.

\subsection{Matéria prima}

A matéria prima utilizada para a realização das análises foram grãos íntegros crus e cozidos de grão de bico sem e com irradiação nas doses de 2, 4, 6, 8 e 10 kGy e posteriormente submetidos a cocção, adquiridos no comércio local de Piracicaba$S P$, da variedade Kabuli.

\subsection{Análises químicas}

\subsubsection{Preparo das amostras}

As amostras foram acondicionadas em porções de $500 \mathrm{~g}$ em sacos de polietileno. As amostras que sofreram o processo de irradiação foram enviadas ao Laboratório de Irradiação de Alimentos e Radioentomologia do CENA/USP, Piracicaba$\mathrm{SP}$, para que o processo fosse realizado num irradiador de Cobalto-60 modelo Gammabeam 650, Otawa, Canadá, sob taxa de dose 0,9696 kGy/h.

Os grãos crus, irradiados e não irradiados, foram triturados em moinhos de facas, peneirados em malha de 30 "mesh", obtendo-se assim as farinhas que foram utilizadas para as análises químicas. Esta farinha foi armazenada em saco de polietileno, fechado, em temperatura de refrigeração $\left(4^{\circ} \mathrm{C}\right)$ até a realização das análises. 
Os grãos crus irradiados e não irradiados, destinados ao processo de cocção foram colocados de remolho em água destilada na proporção de 1:3 (grão:água) e cozidos na proporção de 1:2 (grão:água) à $121^{\circ} \mathrm{C}$ em autoclave por 10 minutos conforme a metodologia sugerida por Molina et al. (1975). Após o cozimento as amostras foram colocadas em bandejas de alumínio e secas em estufa de circulação de ar forçado à temperatura de $50-55^{\circ} \mathrm{C}$ até peso constante (aproximadamente 24 horas). O material foi posteriormente moído e armazenado.

\subsubsection{Composição centesimal}

Para a análise da composição centesimal foram utilizados grão crus e cozidos que não passaram pelo processo de irradiação.

As análises para a determinação dos teores de matéria seca, proteína bruta, extrato etéreo e de cinzas foram realizadas de acordo com a metodologia indicada pela AOAC (1995).

Para determinação do teor de matéria seca, foi utilizado o método gravimétrico em que as amostras foram secas em estufa a $105^{\circ} \mathrm{C}$, até peso constante.

O teor de nitrogênio total foi determinado pelo método microkjeldahl, sendo o teor protéico determinado multiplicando-se o conteúdo de nitrogênio total pelo fator 6,25 .

O extrato etéreo foi determinado utilizando-se extrator de Sohxlet. $\mathrm{Na}$ extração foi utilizado como solvente éter etílico à temperatura de $45-50^{\circ} \mathrm{C}$ em refluxo contínuo da amostra por 6 horas. Recuperado o éter etílico, os tubos foram retirados e colocados em estufa por 20 minutos a $100^{\circ} \mathrm{C}$, deixando esfriar em dessecador e pesados, obtendo-se a quantidade de lipídeos por diferença do peso do tubo.

As cinzas foram determinadas incinerando a amostra em mufla a temperaturas de $550-600^{\circ} \mathrm{C}$ por 4 horas.

O teor de fibra dietética foi determinado pelo método enzimático de acordo com o Total (2000). 


\subsubsection{Composição mineral}

Para a análise da composição mineral foram utilizados grão crus e cozidos que não passaram pelo processo de irradiação.

Os teores de minerais foram determinados pelo método descrito por Sarruge e Haag (1974), sendo utilizada a digestão com ácido nítrico e ácido perclórico a $50^{\circ} \mathrm{C}$ por 10 a 15 minutos, depois $100^{\circ} \mathrm{C}$ até digerir todo o material, chegando à temperatura de $150^{\circ} \mathrm{C}$. Após resfriamento e diluição do material com água desmineralizada, foi realizada a leitura em espectrofotômetro de absorção atômica modelo PERKIN-ELMER 360 . Foram utilizados os seguintes comprimentos de ondas: $422,7 \mathrm{~nm}$ para cálcio; 324 $\mathrm{nm}$ para cobre, $248,3 \mathrm{~nm}$ para ferro, $285,2 \mathrm{~nm}$ para magnésio, $279,5 \mathrm{~nm}$ para manganês e 213,9 nm para zinco. O potássio e o fósforo foram determinados em espectrofotômetro colorimétrico com o comprimento de onda de $420 \mathrm{~nm}$.

\subsubsection{Digestibilidade da proteína "in vitro"}

Para a análise da digestibilidade da proteina "in vitro" foram utilizados grão crus e cozidos irradiados nas doses de 0, 2, 4, 6, 8 e $10 \mathrm{kGy}$.

A digestibilidade "in vitro" foi determinada segundo metodologia descrita por Akeson \& Stahman (1964), a qual se baseia na hidrólise enzimática das proteínas com pepsina e pancreatina, seguida da determinação do nitrogênio não precipitável com ácido pícrico. A amostra foi misturada com solução de pepsina na concentração de 3 $\mathrm{mg} / \mathrm{mL}$ em $\mathrm{HCl} 0,1 \mathrm{~N}$ e deixada a $37^{\circ} \mathrm{C}$ por 3 horas. Posteriormente foi neutralizada com $\mathrm{NaOH} 0,1 \mathrm{~N}$ e adicionada solução de pancreatina na concentração de $0,4 \%$ em tampão fosfato $0,1 \mathrm{M}$ a pH 8,0 sendo incubada a mistura por 24 horas sob agitação a $37^{\circ} \mathrm{C}$. Posteriormente, foi centrifugado a $11.000 \mathrm{rpm}$ por 15 minutos, foi acrescentado, para cada parte do sobrenadante, 5 partes de ácido pícrico, sendo determinado o nitrogênio através de destilador microkjeldahl.

\subsubsection{Perfil de aminoácido}

Para a análise do perfil de aminoácidos foram utilizados grão crus e cozidos irradiados nas doses de 0, 2, 4, 6, 8 e $10 \mathrm{kGy}$. 
Nas amostras anteriormente desengorduradas com éter etílico em extrator de Soxhlet foram determinadas a composição e a concentração dos aminoácidos de acordo com a técnica proposta por Spackman et al (1958) que consiste na separação dos mesmos em resina sulfonada, de troca catiônica, utilizando uma série de tampões como eluentes. Após serem submetidos à hidrólise ácida $\left(\mathrm{HCl} 6 \mathrm{~N}\right.$ a $110^{\circ} \mathrm{C}$ por 22 horas), os aminoácidos foram quantificados em Autoanalisado Beckman Aminoacid (Spies, 1957; Moore \& Stein, 1963).

\subsubsection{Disponibilidade de ferro "in vitro"}

Para a análise de disponibilidade de ferro "in vitro" foram utilizados grão crus e cozidos irradiados nas doses de 0, 2, 4, 6, 8 e $10 \mathrm{kGy}$.

Foi realizada diálise de ferro segundo método proposto por Luten et al. (1996). Os grãos foram submetidos à digestão "in vitro" e o material obtido foi colocado em saco de diálise e o ferro dialisado.

\subsection{Análise estatística}

Os resultados das análises descritas nos itens anteriores,foram realizadas em triplicata. O delineamento estatístico foi inteiramente ao acaso com comparação das médias de repetições obtidas nos diferentes tratamentos analisadas pelo teste $\mathrm{F} \mathrm{e}$ posteriormente pelo método de Tukey (5\%) segundo Pimentel-Gomes (1982). Foi utilizado para análise o software Statistical Analysis System (1996). 


\section{RESULTADOS E DISCUSSÃO}

\subsection{Composição centesimal}

A composição centesimal das amostras de grão-de-bico crus e cozidos, utilizados no presente experimento são apresentados na Figura 2 .

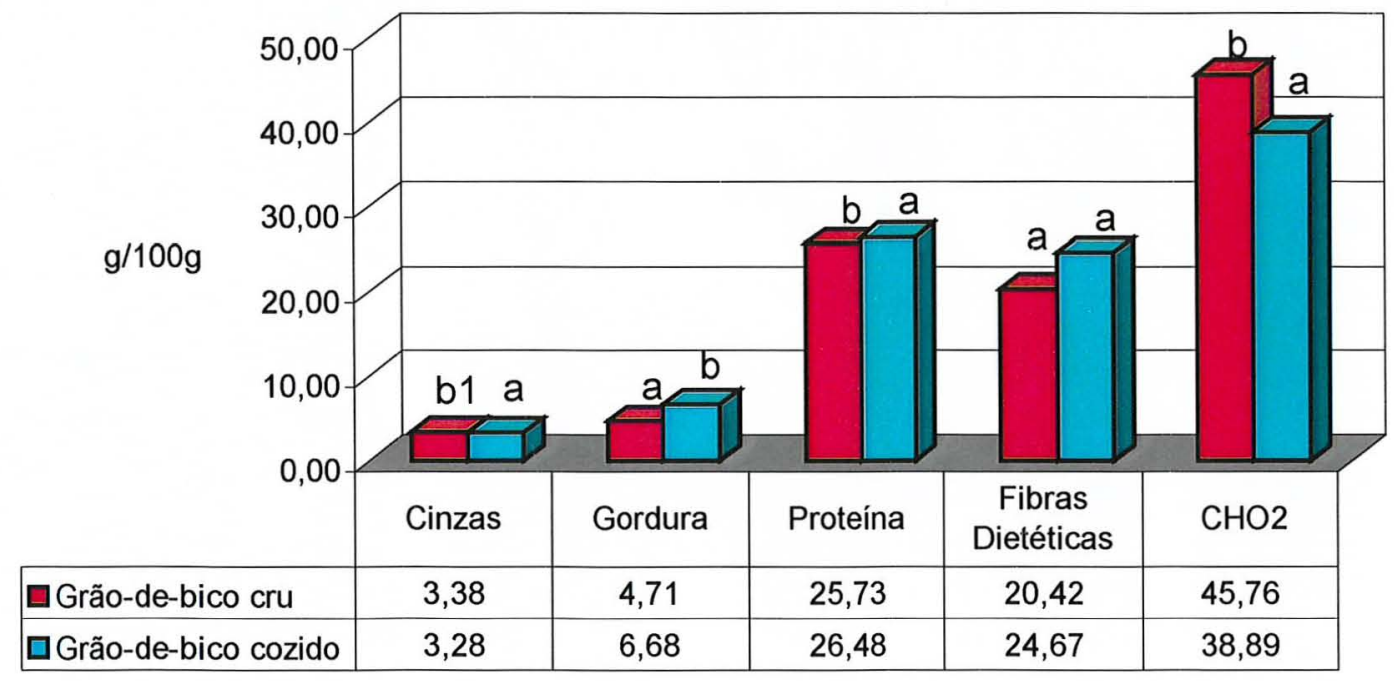

Figura 2 - Composição centesimal (g/100g) das amostras de grão-de-bico cruas e cozidas expressos na base seca

${ }^{1}$ Letras diferentes no mesmo componente indicam diferença significativa entre as médias $(p \leq 0,05)$

${ }^{2}$ Carboidrato por diferença estão inclusos todos os carboidratos disponíveis e não disponíveis 


\begin{tabular}{|l|c|c|}
\hline Composição centesimal & Grão-de-bico cru & Grão-de-bico cozido \\
\hline Umidade & 10,8 a 11,53 & 60,21 a 75,9 \\
\hline Cinzas & 2,71 a 3,61 & 2,31 a 3,73 \\
\hline Gordura & 6,83 a 7,62 & 5,21 a 7,47 \\
\hline Proteína & 18,83 a 21,82 & 10,37 a 22,27 \\
\hline Fibras dietéticas & 3,84 a 23,23 & 19,10 a 23,23 \\
\hline Carboidratos $^{1}$ & 67,83 a 69,96 & 68,91 a 78,42 \\
\hline
\end{tabular}

Quadro 2 - Valores de referência g/100g para a composição centesimal do grão-de-bico cru e cozido de acordo com o Instituto Brasileiro de Geografia e Estatisticas (1996), Tabela de Composição de Alimentos (2001), Latinfoods (2000) e USDA (2004), base seca

\section{${ }^{1}$ Carboidratos por diferença}

Na base fresca, o teor de umidade do grão-de-bico cozido $(72,44 \%)$ encontrado foi maior devido a maceração realizada antes da cocção, embora apresente valor de acordo com a literatura (Quadro 2). Para o grão-de-bico cru $(8,17 \%)$ com faixa de variação 10,80 a $11,53 \%$, podemos observar que o grão apresentou valor baixo do esperado, o que é desejável para melhor conservação do grão.

Tanto o grão-de-bico cru como o cozido, apresentaram teores de cinzas dentro da faixa de variação $2,71 \mathrm{~g} / 100 \mathrm{~g}$ a $3,61 \mathrm{~g} / 100 \mathrm{~g}$ e $2,31 \mathrm{~g} / 100 \mathrm{~g}$ a $3,73 \mathrm{~g} / 100 \mathrm{~g}$ respectivamente para grão crus e cozidos (Quadro 2). Moreno et al. (2000) estudando o grão-de-bico cru encontrou valores para o teor de cinzas de 2,79 a 2,98\%, valor este abaixo dos encontrado neste trabalho.

O teor de gordura para o grão cru e cozido pode variar $6,83 \mathrm{~g} / 100 \mathrm{~g}$ a 7,62 $\mathrm{g} / 100 \mathrm{~g}$ e $5,21 \mathrm{~g} / 100 \mathrm{~g}$ a $7,47 \mathrm{~g} / 100 \mathrm{~g}$ respectivamente (Quadro 2), portanto foi encontrado valor menor para o grão-de-bico cru, sendo que o grão-de-bico cozido apresentou valor semelhante. Queiroz et al (2002), estudarão a composição centesimal em leguminosas cruas liofilizadas. As leguminosas avaliadas foram: ervilha (Pisum 
sativum), feijão-comum (Phaseulus vulgaris), grão-de-bico (Cicer arietinum) e lentilha (Lens culinaris). Verificaram que o grão-de-bico apresentou teor de lipídeos totais aproximadamente três vezes maior que das demais leguminosas.

De acordo com Quadro 2, o teor de proteina do grão-de-bico cru e cozido apresentaram valores acima do esperado $(18,83 \mathrm{~g} / 100 \mathrm{~g}$ a $21,82 \mathrm{~g} / 100 \mathrm{~g}$ e $10,37 \mathrm{~g} / 100 \mathrm{~g}$ a $22,27 \mathrm{~g} / 100 \mathrm{~g}$ respectivamente), aproximando-se do valor encontrado por Moreno et al. (2000) que foi de $22,53 \%$ no grão cru, sendo que o grão-de-bico cozido neste apresentou valores adequados. Segundo Dilawari et al. (1981) e Braga (1997) o conteúdo de proteína bruta das sementes de grão-de-bico varia de 12,4 a $31,5 \%$, concordando com o resultado encontrado para o grão-de-bico cru.

A fibra dietética é importante constituinte do grão-de-bico. Os valores encontrados neste trabalho ficaram acima do esperados para o grão cozido, isto se deve porque o grão utilizado estava integro e o teor de fibra está relacionada com o teor de tegumento das sementes. Astiasaran et al (1997) estudando a composição centesimal do grão-de-bico encontram valores 27,81; 29,64 e 27,57 respectivamente para o grão cru, cozido e em banho-maria, valores estes superiores ao encontrados neste trabalho.

Tanto para os valores encontrados no Quadro 2, como num estudo realizado por Braga (1997) onde o teor de carboidratos variam de 52,5 a $70,9 \%$, podemos verificar que o conteúdo total de carboidratos está de abaixo dos citado nestas literaturas. Em estudo realizado por Astiasaran et al (1997) os valores encontrados para o carboidratos no grão-de-bico foi de 50,54 e 43,34 para o grão cru e cozido respectivamente e que, o processo de cocção não diferiram estatisticamente a nível de significância $p \leq 0,01 \%$. No nosso trabalho a cocção apresentou diferença no conteúdo total de carboidratos, sendo que o grão-de-bico cru apresentou maior quantidade deste. 


\subsection{Composição mineral}

O conteúdo de minerais das amostras de grão-de-bico crus e cozidos são apresentados na Figura 3

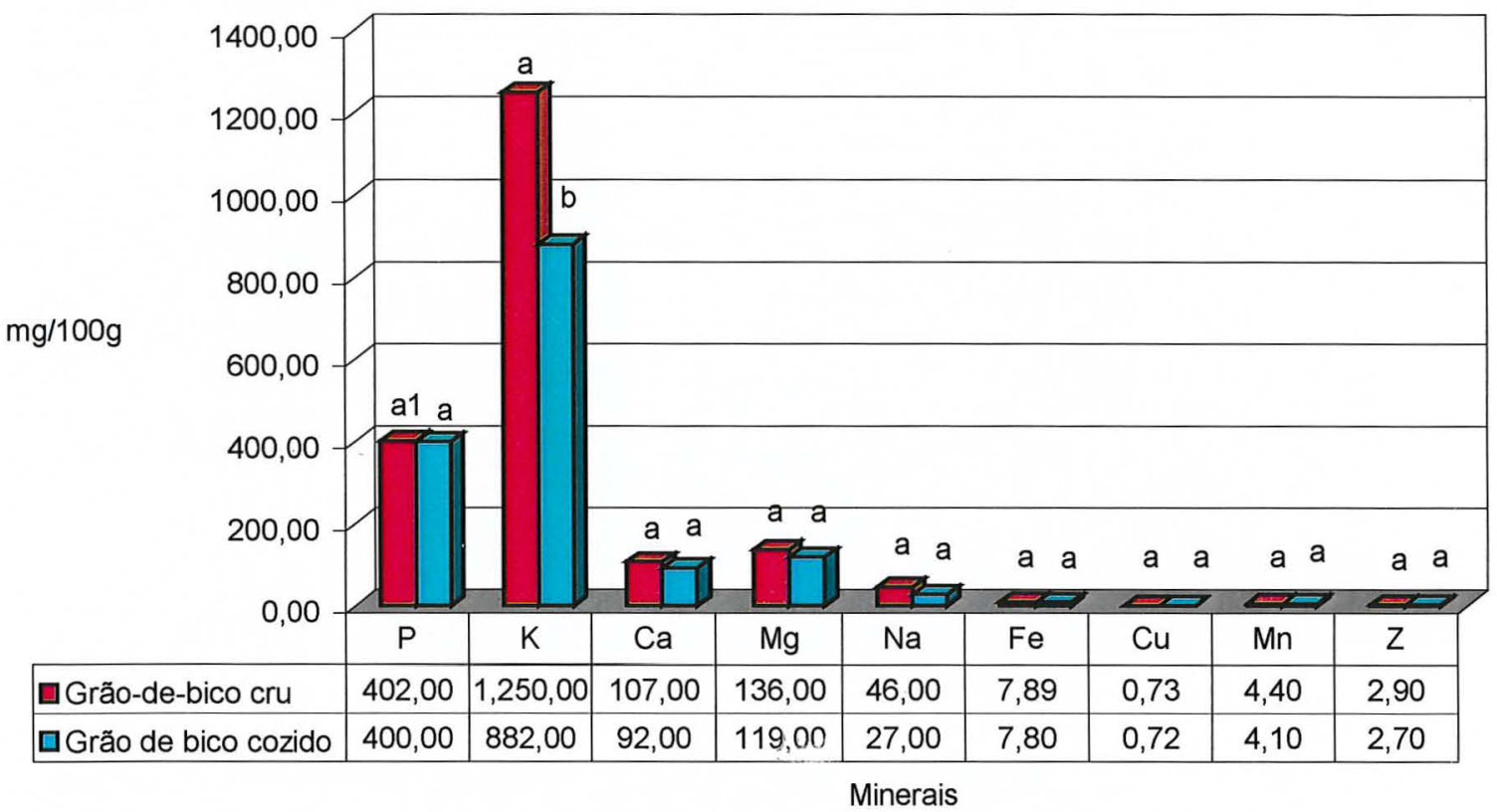

Figura 3 - Composição mineral em mg/100g nas amostras de grão de bico cru e cozido expressos na base seca

${ }^{1}$ Letras diferentes no mesmo elemento mineral indicam diferença significativa entre as médias $(p \leq 0,05)$ 


\begin{tabular}{|l|c|c|}
\hline \multicolumn{1}{|c|}{ Minerais } & Grão-de-bico Cru & Grão-de-bico Cozido \\
\hline Fósforo & 366,00 & 168,00 \\
\hline Potássio & 875,00 & 291,00 \\
\hline Cálcio & 105,00 & 49,00 \\
\hline Magnésio & 115,00 & 48,00 \\
\hline Sódio & 24,00 & 7,00 \\
\hline Ferro & 6,24 & 2,89 \\
\hline Cobre & 0,84 & 0,35 \\
\hline Manganês & 2,20 & 1,03 \\
\hline Zinco & 3,43 & 1,53 \\
\hline
\end{tabular}

Quadro 3 - Valores de referência $\mathrm{mg} / 100 \mathrm{~g}$ para a composição mineral do grão-de-bico cru e cozido de acordo com o USDA (2004), base seca

De acordo os dados do Quadro 3 a composição dos minerais do grão-de-bico, demonstra que esta leguminosa é excelente fonte de fósforo, potássio, cálcio, magnésio, sódio, ferro, manganês, cálcio, cobre, manganês e zinco, o mesmo ocorreu em estudo realizado por Avancini (1992) onde estudando a composição mineral do grão-de-bico verificou que este é boa fonte de fósforo, magnésio, ferro, potássio e manganês.

Pode-se observar que as amostras submetidas a cocção não diferiram estatisticamente do grão-de-bico cru, exceto o potássio, e que embora houve uma sensivel diminuição nos teores de fósforo, potássio, cálcio, magnésio, ferro, cobre, manganês e zinco, estes elementos apresentaram valores dentro do esperado (Quadro 3), com exceção do potássio que apresentou valor acima. De acordo com Chavan et al (1988), com a cocção, os minerais sofrem uma redução de 0,3 a $0,5 \%$ em relação à semente crua.

Adawy (2002) estudando a composição mineral do grão-de-bico observou que o cozimento reduziu o cobre, ferro e potássio na proporção de $15 \%, 8 \%$ e $24 \%$ respectivamente.

Podemos observar que a cocção causa diminuição na quantidade de minerais, como o que ocorreu com o potássio. Esta diminuição, no entanto, não é preocupação 
em relação ao valor nutricional quando ingerimos sementes integras, uma que de acordo com a Avancini (1992) alguns minerais podem estar contidos em maior proporção na casca e sua retirada pode dinimuir o teor de mineral. Isto justifica o valor encontrado neste trabalho que foi superior ao proposto pela literatura (Quadro 3).

\subsection{Digestibilidade protéica}

A determinação da digestibilidade de proteína "in vitro" é um dos fatores a ser levado em consideração na qualidade da proteína.

A digestibilidade protéica "in vitro" das amostras de grão-de-bico cru e cozido e, seu comportamento nas doses de radiação de 0 , 2, 4, 6, 8 e 10 kGy estão expressos na Figura 4. 


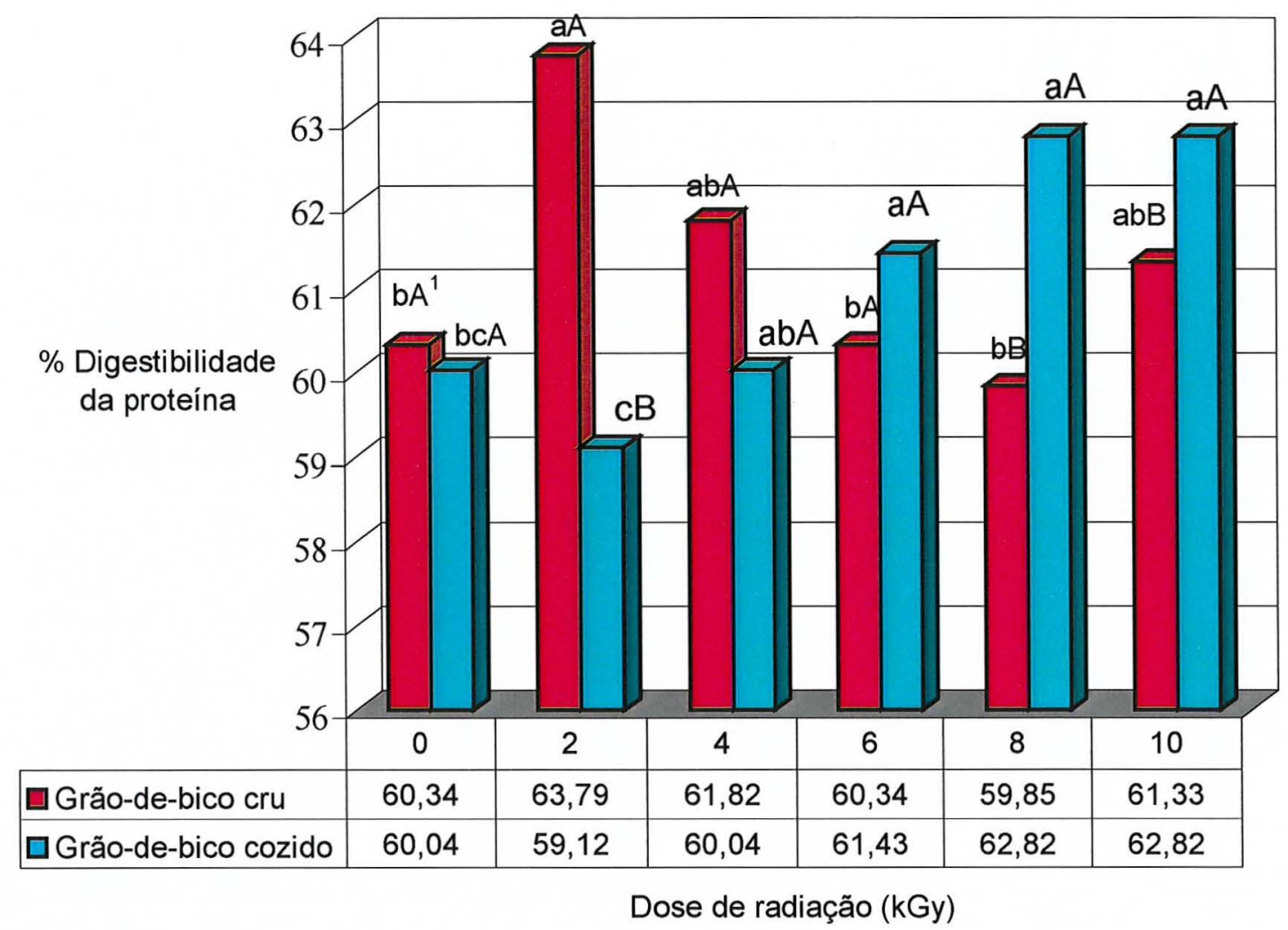

Figura 4 - Digestibilidade da proteína "in vitro" do grão-de-bico irradiados nas doses de radiação $0,2,4,6$, 8 e 10 kGy

${ }^{1}$ Valores contendo letras iguais sobrescritas minúscula para comparação entre cru nos tratamentos a 0, 2, 4, 6, 8 e 10kGy e cozido no tratamento a 0, 2, 4, 6, 8 e 10kGy e maiúsculas para comparação entre cru e cozido, não apresentam diferenças significativas $(p \leq 0,05)$

Pode-se observar que a dose $2 \mathrm{kGy}$ resultou em melhor digestibilidade para o grão cru, seguida da dose 4 e 10 kGy que não diferiu estatisticamente das outras doses, porém o grão-de-bico cru não é consumido na alimentação humana. Para o grão cozido as doses de 8 e $10 \mathrm{KGy}$ obtiveram as mesmas médias, mas não diferiu estatisticamente da dose 6 que difere das demais, podemos concluir através deste resultado que com as maiores doses foram obtidos as melhores digestibilidades devido a alterações que ocorreram no grão pela irradiação, uma vez que o tratamento térmico 
pode influenciar positivamente a digestibilidade das proteinas do grão-de-bico. No estudo de Tavano (2002) não houve diferença entre amostras cruas e cozidas.

Comparando-se os tratamentos pode-se observar que nas doses de 0,4 e 6 kGy a cocção não influenciou na digestibilidade da proteína, mas no tratamento que recebeu radiação de 2, 8 e 10 kGy o tratamento influenciou na digestibilidade protéica, sendo que o grão-de-bico cozido apresentou uma melhor digestibilidade em doses maiores de radiação. A cocção melhora a digestibilidade dos grãos proporcionando melhor aproveitamento dos nutrientes, entre eles a proteina.

Os valores deste trabalho foram bem inferiores aos observados por Monsoor et al. (2002) que avaliando a digestibilidade protéica "in vitro" encontrou $89,01 \%$ para o grão-de-bico cru e 96,94\% para o cozido. Em estudo realizado por Adaway (2002) encontrou valores para a digestibilidade protéica 83,61 e 89,96 para o grão cru e cozido respectivamente. Esta diferença provavelmente se deva ao tipo de material analisado.

De acordo com Braga et al (1992) o grão-de-bico consumido no Brasil é na sua totalidade do tipo kabuli, pode-se observar que os valores encontrados para a digestibilidade da proteina do grão estão próximos aos citados por Singh \& Jambunatam (1981) para esse cultivar que encontraram valores para a digestbilidade 63,7 a $76 \%$. Carrillo (2000) estudando a digestibilidade protéica do grão-de-bico cru encontrou valor de $72,7 \%$, concordando com os valores encontrados por estes autores. Alguns fatores que influenciam na digestibilidade seriam o endurecimento do grão, que tem efeito prejudicial sobre a qualidade protéica, o que causa significante redução na digestibilidade da proteina "in vitro" e em "in vivo", outros fatores de cultivo também podem influenciar a digestibilidade (Moreno et al, 2000).

Moreno (2000) estudando feijão preto, observaram diminuição na digestibilidade proteica "in vitro" desde quando armazenados a 30 e $40^{\circ} \mathrm{C}$ e umidade relativa de $80 \%$, o que poderia ter resultado em uma digestibilidade baixa.

Monsoor et al. (2002) comparando grão-de-bico e lentilha observaram que a cocção tem efeito posivito na digestibilidade da proteína em lentilha e grão-de-bico, aumentando sua digestibilidade de $95,19 \%$ para $97,90 \%$ e 89,01 para $96,94 \%$ para grão crus e cozidos respectivamente. No presente estudo podemos observar que houve interação da radiação na digestibilidade da proteína nas doses 0,2 e $4 \mathrm{kGy}$ pois o grão cru apresentou melhor digestibilidade. No que se refere as doses de 6, 8 e 10kG o grão-de-bico cozido apresentou melhor digestibilidade concordando com os resultados 
encontrados no estudo de Monsoor et al. Uma possível explicação seria que com a cocção há desmaturação dos inibidores de protease, sendo que não ocorreram no grão cru na baixa dose de radiação.

Khokar et al. (1986) observaram que com a cocção os fatores antinutricionais são reduzidos ou eliminados. Acarretando uma inibição na atividade dos inibidores de tripsina (Márquez et al. 1998) favorecendo a digestibilidade proteica. Uma vez que o grão na forma crua não é consumido por humanos e, estes fatores são inativados pelo aquecimento o que benificiará a digestibilidade da proteína.

\subsection{Ferro dialisável}

Os resultados encontrados para ferro dialisável "in vitro" das amostras de grãode-bico cru e cozido são apresentados na Figura 5 


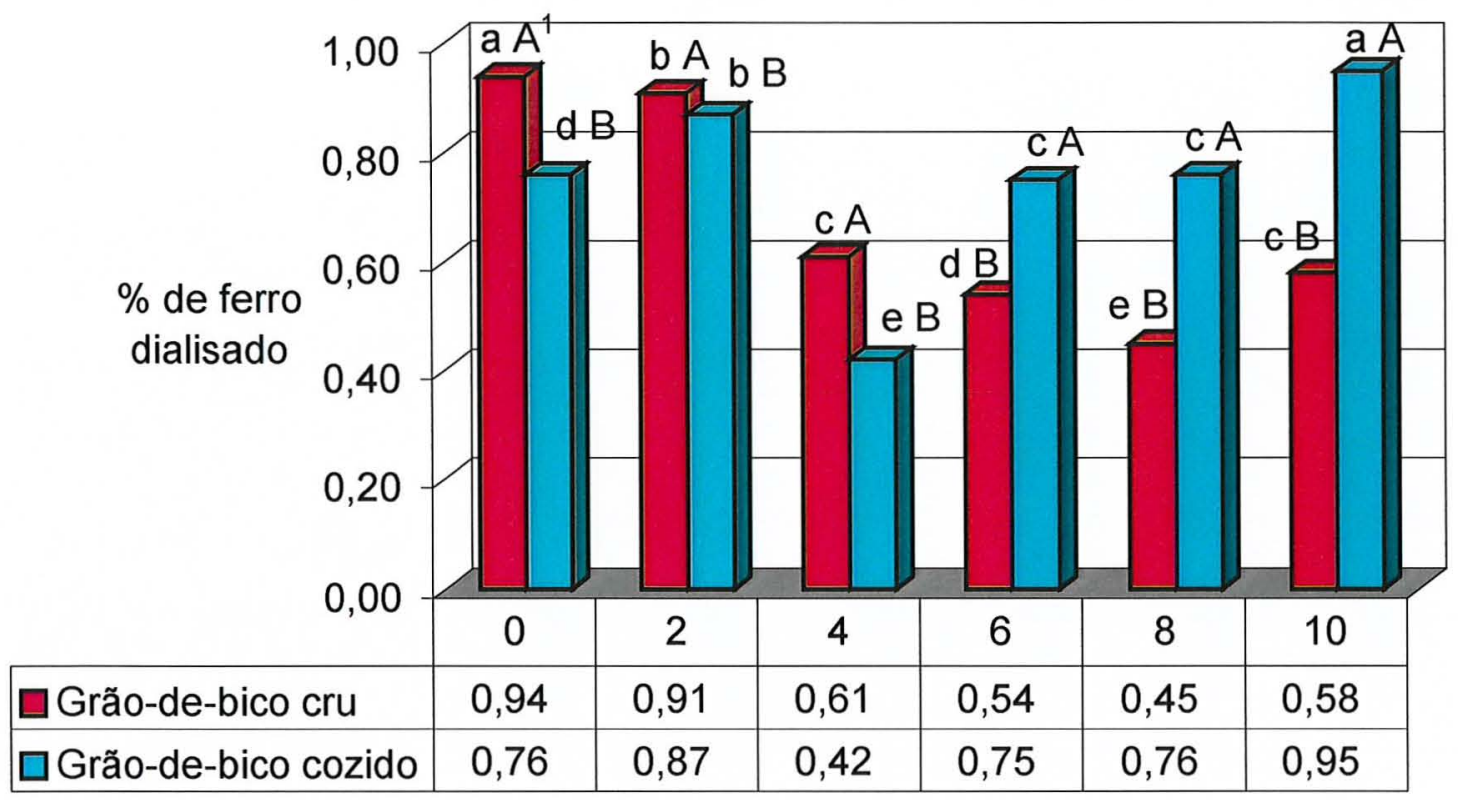

Dose de radiação (kGy)

Figura 5 - Porcentagem de ferro dialisável "in vitro" de grão-de-bico cru e cozido nas doses de radiação de $0,2,4,6,8$ e $10 \mathrm{kGy}$

${ }^{1}$ Valores contendo letras iguais sobrescritas minúscula para comparação entre cru nos tratamentos a 0, 2, 4, 6, 8 e 10kGy e cozido no tratamento a 0, 2, 4, 6, 8 e 10kGy e maiúsculas para comparação entre cru e cozido, não apresentam diferenças significativas $(p \leq 0,05)$

O método da diálise de ferro "in vitro" é útil para uma avaliação preliminar, sendo indicativa da biodisponibilidade relativa do elemento presente em um alimento. Apresenta boa correlação com o método "in vivo" feito com seres humano. Baseia-se, fundamentalmente, na simulação da digestão do alimento, seguida de uma diálise em membrana semi-permeável (Germano, 2002).Portanto é um ótimo indicador de como o ferro presente no grão-de-bico está biodisponível,.sendo utilizado pelo organismo em seu metabolismo celular.

De acordo com Boccia (1991) a absorção de ferro "in vivo" é de 0,84 a 1,19\%. Os melhores tratamentos encontrados neste trabalho foram para o cru a OkGy e $2 \mathrm{kGy}$ e cozido 2kGy e 10kGy. 
Pode-se observar (Figura 5), que as médias diminuíram com o aumento da dose de irradiação para as amostras cruas. Para o grão-de-bico cozido as médias aumentaram com o aumento da dose de irradiação, isso se deve ao processo de maceração e cocção que foi empregado, além da irradiação. A influência da maceração e cocção já foi constatada na digestibilidade da proteína.

Pinn (1992) verificou que, em função da dose empregada, ocorre aumento da porcentagem de ferro dialisável. Com doses de 2, 4, 6, 8 e $10 \mathrm{KGy}$ foram observados aumentos de aproximadamente $11,13,23,57$ e $70 \%$ em relação à porcentagem de ferro dialisável do feijão não irradiado $(0,82 \%)$.

Comparando-se os tratamentos com a irradiação pode-se observar que o grãode-bico cru apresentou melhor diálise de ferro nas doses 0,2 e 4 kGy. $O$ grão-de-bico cozido apresentou comportamento contrário ao grão cru e apresentou melhor diálise de ferro conforme o aumento da dose de radiação, sendo maior que no cru para as doses de 6,8 e $10 \mathrm{kGy}$. Isso ocorreu provavelmente, devido às alterações nas cadeias de aminoácidos após a irradiação, maceração e cocção, apresentado maior quantidade de aminoácidos livres o que propicia a disponibilidade do ferro.

\subsection{Aminograma}

Os resultados obtidos na análise do aminograma das amostras de grão-de-bico cru e cozido irradiados são apresentados nas tabelas 1, 2, 3, 4 e 5 e nos quadros 6 e 7. 
Tabela 1. Composição em $\mathrm{mg}$ de aminoácidos $/ 100 \mathrm{mg}$ proteína na amostra irradiada de grão-de-bico cru nas doses de radiação de 0,6 , e 10 kGy

\begin{tabular}{lccc}
\hline \multicolumn{1}{c}{ Aminoácidos/ } & \multicolumn{3}{c}{ mg de aminoácido /100 mg proteina } \\
\cline { 2 - 4 } Dose de radiação & $0 \mathrm{kGy}$ & $6 \mathrm{kGy}$ & $10 \mathrm{kGy}$ \\
\hline Acido Aspartico & $11,99^{\mathrm{c}}$ & $13,60^{\mathrm{a}}$ & $12,54^{\mathrm{b}}$ \\
Treonina & $3,31^{\mathrm{c}}$ & $3,60^{\mathrm{a}}$ & $3,52^{\mathrm{b}}$ \\
Serina & $5,08^{\mathrm{c}}$ & $5,51^{\mathrm{a}}$ & $5,25^{\mathrm{b}}$ \\
Acido Glutâmico & $17,80^{\mathrm{c}}$ & $19,92^{\mathrm{a}}$ & $18,47^{\mathrm{b}}$ \\
Prolina & $4,11^{\mathrm{b}}$ & $4,58^{\mathrm{a}}$ & $4,03^{\mathrm{c}}$ \\
Glicina & $3,94^{\mathrm{c}}$ & $4,24^{\mathrm{a}}$ & $4,03^{\mathrm{b}}$ \\
Alanina & $4,07^{\mathrm{c}}$ & $4,49^{\mathrm{a}}$ & $4,19^{\mathrm{b}}$ \\
Cistina & $0,93^{\mathrm{c}}$ & $0,93^{\mathrm{a}}$ & $0,93^{\mathrm{b}}$ \\
Valina & $3,73^{\mathrm{c}}$ & $4,07^{\mathrm{a}}$ & $3,81^{\mathrm{b}}$ \\
Metionina & $0,55^{\mathrm{c}}$ & $0,51^{\mathrm{b}}$ & $0,64^{\mathrm{a}}$ \\
Isoleucina & $3,56^{\mathrm{c}}$ & $4,03^{\mathrm{a}}$ & $3,64^{\mathrm{b}}$ \\
Leucina & $6,95^{\mathrm{c}}$ & $7,80^{\mathrm{a}}$ & $7,37^{\mathrm{b}}$ \\
Tirosina & $2,42^{\mathrm{c}}$ & $2,75^{\mathrm{a}}$ & $2,50^{\mathrm{b}}$ \\
Fenilalanina & $5,81^{\mathrm{c}}$ & $6,57^{\mathrm{a}}$ & $5,39^{\mathrm{b}}$ \\
Lisina & $6,57^{\mathrm{c}}$ & $7,16^{\mathrm{a}}$ & $6,91^{\mathrm{b}}$ \\
Amônia & $1,74^{\mathrm{c}}$ & $1,95^{\mathrm{a}}$ & $1,86^{\mathrm{b}}$ \\
Histidina & $2,54^{\mathrm{c}}$ & $3,35^{\mathrm{a}}$ & $2,50^{\mathrm{c}}$ \\
Arginina & $10,17^{\mathrm{c}}$ & $11,57^{\mathrm{a}}$ & $10,51^{\mathrm{b}}$ \\
\hline & & &
\end{tabular}

${ }^{1}$ Valores contendo letras iguais sobrescritas (maiúscula para linhas) não apresentam diferenças significativas $(p \leq 0,05)$ 
Tabela 2. Composição em mg de aminoácidos/100 mg proteína na amostra irradiada de grão-de-bico cozido nas doses de radiação de 0,6 , e $10 \mathrm{kGy}$

\begin{tabular}{lccc}
\hline \multicolumn{1}{c}{ Aminoácidos/ } & \multicolumn{3}{c}{ mg de aminoácido $/ 100 \mathrm{mg}$ proteina } \\
\cline { 2 - 4 } Dose de radiação & $0 \mathrm{kGy}$ & $6 \mathrm{kGy}$ & $10 \mathrm{kGy}$ \\
\hline Acido Aspartico & $11,87^{\mathrm{b1}}$ & $11,51^{\mathrm{c}}$ & $12,02^{\mathrm{a}}$ \\
Treonina & $3,29^{\mathrm{b}}$ & $3,25^{\mathrm{c}}$ & $3,45^{\mathrm{a}}$ \\
Serina & $4,96^{\mathrm{b}}$ & $4,88^{\mathrm{c}}$ & $5,08^{\mathrm{a}}$ \\
Acido Glutâmico & $17,26^{\mathrm{b}}$ & $17,22^{\mathrm{c}}$ & $18,57^{\mathrm{a}}$ \\
Prolina & $3,93^{\mathrm{b}}$ & $3,81^{\mathrm{c}}$ & $3,97^{\mathrm{a}}$ \\
Glicina & $3,81^{\mathrm{b}}$ & $3,77^{\mathrm{c}}$ & $3,97^{\mathrm{a}}$ \\
Alanina & $4,01^{\mathrm{b}}$ & $3,97^{\mathrm{c}}$ & $4,21^{\mathrm{a}}$ \\
Cistina & $0,75^{\mathrm{c}}$ & $0,83^{\mathrm{b}}$ & $0,87^{\mathrm{a}}$ \\
Valina & $3,77^{\mathrm{c}}$ & $3,93^{\mathrm{b}}$ & $4,13^{\mathrm{a}}$ \\
Metionina & $0,63^{\mathrm{b}}$ & $0,99^{\mathrm{b}}$ & $1,19^{\mathrm{a}}$ \\
Isoleucina & $3,81^{\mathrm{b}}$ & $3,81^{\mathrm{b}}$ & $3,97^{\mathrm{a}}$ \\
Leucina & $7,14^{\mathrm{b}}$ & $7,02^{\mathrm{c}}$ & $7,38^{\mathrm{a}}$ \\
Tirosina & $2,42^{\mathrm{b}}$ & $2,34^{\mathrm{c}}$ & $2,52^{\mathrm{a}}$ \\
Fenilalanina & $5,83^{\mathrm{b}}$ & $5,71^{\mathrm{c}}$ & $5,87^{\mathrm{a}}$ \\
Lisina & $6,39^{\mathrm{a}}$ & $5,91^{\mathrm{c}}$ & $6,07^{\mathrm{b}}$ \\
Amônia & $1,67^{\mathrm{b}}$ & $1,71^{\mathrm{c}}$ & $1,83^{\mathrm{a}}$ \\
Histidina & $2,70^{\mathrm{b}}$ & $2,78^{\mathrm{a}}$ & $1,59^{\mathrm{c}}$ \\
Arginina & $9,84^{\mathrm{b}}$ & $9,44^{\mathrm{c}}$ & $9,25^{\mathrm{a}}$ \\
\hline
\end{tabular}

${ }^{1}$ Valores contendo letras iguais sobrescritas (minúsculas para linhas) não apresentam diferenças significativas $(p \leq 0,05)$ 
Tabela 3. Composição em $\mathrm{mg}$ de aminoácidos $/ 100 \mathrm{mg}$ proteina na amostra irradiada de grão-de-bico cru e cozido na dose de radiação de 0 kGy

\begin{tabular}{lcc}
\hline \multicolumn{1}{c}{ Aminoácidos/ } & Grão-de-bico cru & Grão-de-bico cozido \\
\cline { 2 - 3 } \multicolumn{1}{c}{ Dose de radiação } & OkGy & $0 k G y$ \\
\hline Acido Aspartico & $11,99^{\mathrm{a} 1}$ & $11,87^{\mathrm{b}}$ \\
Treonina & $3,31^{\mathrm{a}}$ & $3,29^{\mathrm{b}}$ \\
Serina & $5,08^{\mathrm{a}}$ & $4,96^{\mathrm{b}}$ \\
Acido Glutâmico & $17,80^{\mathrm{a}}$ & $17,26^{\mathrm{b}}$ \\
Prolina & $4,11^{\mathrm{a}}$ & $3,93^{\mathrm{b}}$ \\
Glicina & $3,94^{\mathrm{a}}$ & $3,81^{\mathrm{b}}$ \\
Alanina & $4,07^{\mathrm{a}}$ & $4,01^{\mathrm{b}}$ \\
Cistina & $0,93^{\mathrm{a}}$ & $0,75^{\mathrm{b}}$ \\
Valina & $3,73^{\mathrm{b}}$ & $3,77^{\mathrm{a}}$ \\
Metionina & $0,55^{\mathrm{b}}$ & $0,63^{\mathrm{a}}$ \\
Isoleucina & $3,56^{\mathrm{b}}$ & $3,81^{\mathrm{a}}$ \\
Leucina & $6,95^{\mathrm{b}}$ & 7,14 \\
Tirosina & $2,42^{\mathrm{a}}$ & $2,42^{\mathrm{a}}$ \\
Fenilalanina & $5,81^{\mathrm{b}}$ & $5,83^{\mathrm{b}}$ \\
Lisina & $6,57^{\mathrm{a}}$ & $6,39^{\mathrm{b}}$ \\
Amônia & $1,74^{\mathrm{a}}$ & $1,67^{\mathrm{b}}$ \\
Histidina & $2,54^{\mathrm{b}}$ & $2,70^{\mathrm{a}}$ \\
Arginina & $10,17^{\mathrm{a}}$ & $9,84^{\mathrm{b}}$ \\
\hline
\end{tabular}

${ }^{1}$ Valores contendo letras iguais sobrescritas (maiúscula para linhas) não apresentam diferenças significativas $(p \leq 0,05)$ 
Tabela 4. Composição em $\mathrm{mg}$ de aminoácidos/100 mg proteina na amostra irradiada de grão-de-bico cru e cozido na dose de radiação de 6 kGy

\begin{tabular}{lcc}
\hline \multicolumn{1}{c}{ Aminoácidos/ } & Grão-de-bico cru & Grão-de-bico cozido \\
\cline { 2 - 3 } \multicolumn{1}{c}{ Dose de radiação } & $6 \mathrm{kGy}$ & $6 \mathrm{kGy}$ \\
\hline Acido Aspartico & $13,60^{\mathrm{a}}$ & $11,51^{\mathrm{b}}$ \\
Treonina & $3,60^{\mathrm{a}}$ & $3,25^{\mathrm{b}}$ \\
Serina & $5,51^{\mathrm{a}}$ & $4,88^{\mathrm{b}}$ \\
Acido Glutâmico & $19,92^{\mathrm{a}}$ & $17,22^{\mathrm{b}}$ \\
Prolina & $4,58^{\mathrm{a}}$ & $3,81^{\mathrm{b}}$ \\
Glicina & $4,24^{\mathrm{a}}$ & $3,77^{\mathrm{b}}$ \\
Alanina & $4,49^{\mathrm{a}}$ & $3,97^{\mathrm{b}}$ \\
Cistina & $0,93^{\mathrm{a}}$ & $0,83^{\mathrm{b}}$ \\
Valina & $4,07^{\mathrm{a}}$ & $3,93^{\mathrm{b}}$ \\
Metionina & $0,51^{\mathrm{b}}$ & $0,99^{\mathrm{a}}$ \\
Isoleucina & $4,03^{\mathrm{a}}$ & $3,81^{\mathrm{b}}$ \\
Leucina & $7,80^{\mathrm{a}}$ & $7,02^{\mathrm{b}}$ \\
Tirosina & $2,75^{\mathrm{b}}$ & $2,34^{\mathrm{a}}$ \\
Fenilalanina & $6,57^{\mathrm{a}}$ & $5,71^{\mathrm{b}}$ \\
Lisina & $7,16^{\mathrm{a}}$ & $5,91^{\mathrm{b}}$ \\
Amônia & $1,95^{\mathrm{a}}$ & $1,71^{\mathrm{b}}$ \\
Histidina & $3,35^{\mathrm{a}}$ & $2,78^{\mathrm{b}}$ \\
Arginina & $11,57^{\mathrm{a}}$ & $9,44^{\mathrm{b}}$ \\
\hline
\end{tabular}

${ }^{1}$ Valores contendo letras iguais sobrescritas (maiúscula para linhas) não apresentam diferenças significativas $(p \leq 0,05)$ 
Tabela 5. Composição em $\mathrm{mg}$ de aminoácidos/100 $\mathrm{mg}$ proteína na amostra irradiada de grão-de-bico cru e cozido na dose de radiação de 10 kGy

\begin{tabular}{lcc}
\hline \multicolumn{1}{c}{ Aminoácidos/ } & Grão-de-bico cru & Grão-de-bico cozido \\
\cline { 2 - 3 } \multicolumn{1}{c}{ Dose de radiação } & $10 \mathrm{kGy}$ & $10 \mathrm{kGy}$ \\
\hline Acido Aspartico & $12,54^{\mathrm{a}}$ & $12,02^{\mathrm{b}}$ \\
Treonina & $3,52^{\mathrm{a}}$ & $3,45^{\mathrm{b}}$ \\
Serina & $5,25^{\mathrm{a}}$ & $5,08^{\mathrm{b}}$ \\
Acido Glutâmico & $18,47^{\mathrm{b}}$ & $18,57^{\mathrm{a}}$ \\
Prolina & $4,03^{\mathrm{a}}$ & $3,97^{\mathrm{b}}$ \\
Glicina & $4,03^{\mathrm{a}}$ & $3,97^{\mathrm{b}}$ \\
Alanina & $4,19^{\mathrm{b}}$ & $4,21^{\mathrm{a}}$ \\
Cistina & $0,93^{\mathrm{a}}$ & $0,87^{\mathrm{b}}$ \\
Valina & $3,81^{\mathrm{b}}$ & $4,13^{\mathrm{a}}$ \\
Metionina & $0,64^{\mathrm{b}}$ & $1,19^{\mathrm{a}}$ \\
Isoleucina & $3,64^{\mathrm{b}}$ & $3,97^{\mathrm{a}}$ \\
Leucina & $7,37^{\mathrm{a}}$ & $7,38^{\mathrm{b}}$ \\
Tirosina & $2,50^{\mathrm{b}}$ & $2,52^{\mathrm{a}}$ \\
Fenilalanina & $5,39^{\mathrm{b}}$ & $5,87^{\mathrm{a}}$ \\
Lisina & $6,91^{\mathrm{a}}$ & $6,07^{\mathrm{b}}$ \\
Amônia & $1,86^{\mathrm{a}}$ & $1,83^{\mathrm{b}}$ \\
Histidina & $2,50^{\mathrm{a}}$ & $1,59^{\mathrm{b}}$ \\
Arginina & $10,51^{\mathrm{a}}$ & $9,25^{\mathrm{b}}$ \\
\hline
\end{tabular}

${ }^{1}$ Valores contendo letras iguais sobrescritas (maiúscula para linhas) não apresentam diferenças significativas $(p \leq 0,05)$ 


\begin{tabular}{|l|c|c|c|c|c|}
\hline \multirow{2}{*}{ Aminoácidos } & \multicolumn{2}{|c|}{ Padrão FAO" } & \multicolumn{3}{c|}{ "Score" (\%) ${ }^{2}$} \\
\cline { 2 - 6 } & $\begin{array}{c}\text { Pré- } \\
\text { escolares }\end{array}$ & Adultos & OkGy & $6 \mathrm{kGy}$ & $10 \mathrm{kGy}$ \\
\hline Treonina & 3,4 & 0,9 & 97,21 & 105,93 & 103,44 \\
\hline Valina & 3,5 & 1,3 & 106,54 & 119,6 & 112,16 \\
\hline $\begin{array}{l}\text { Metionina + } \\
\text { Cistina }\end{array}$ & 2,5 & 1,7 & 59,3 & 57,6 & 62,8 \\
\hline Isoleucina & 2,8 & 1,3 & 127,2 & 143,7 & 130,2 \\
\hline Leucina & 6,6 & 1,9 & 105,3 & 229,3 & 216,9 \\
\hline $\begin{array}{l}\text { Tirosina + } \\
\text { Fenilalanina }\end{array}$ & 6,3 & 1,9 & 130,5 & 373,0 & 335,6 \\
\hline Lisina & 5,8 & 1,6 & 113,2 & 123,5 & 119,0 \\
\hline Histidina & 1,9 & 1,6 & 133,8 & 98,5 & 73,5 \\
\hline
\end{tabular}

Quadro 4 - "Score" de aminoácidos (\%) nas amostras de grão-de-bico cru, nas doses de radiação 0,6 e 10kGy comparado com as necessidades de aminoácidos essenciais em humanos

${ }^{1}$ Padrão FAO para humanos segundo suas necessidades

${ }^{2}$ Resultado representa os percentuais relativos de cada aminoácido ao valor de referência da FAO para pré-escolares 


\begin{tabular}{|l|c|c|c|c|c|}
\hline \multirow{2}{*}{ Aminoácidos } & \multicolumn{2}{|c|}{ Padrão FAO } & \multicolumn{3}{c|}{ Score de aminoácidos $\left.^{1} \%\right)^{2}$} \\
\cline { 2 - 6 } & $\begin{array}{c}\text { Pré- } \\
\text { escolares }\end{array}$ & Adultos & 0kGy & $6 \mathrm{kGy}$ & $10 \mathrm{kGy}$ \\
\hline Treonina & 3,4 & 0,9 & 96,87 & 95,10 & 101,54 \\
\hline Valina & 3,5 & 1,3 & 110,8 & 115,5 & 121,4 \\
\hline $\begin{array}{l}\text { Metionina + } \\
\text { Cistina }\end{array}$ & 2,5 & 1,7 & 55,6 & 73,0 & 82,5 \\
\hline Isoleucina & 2,8 & 1,3 & 136,0 & 136,0 & 141,7 \\
\hline Leucina & 6,6 & 1,9 & 210,1 & 206,6 & 217,1 \\
\hline $\begin{array}{l}\text { Tirosina + } \\
\text { Fenilalanina }\end{array}$ & 6,3 & 1,9 & 131,0 & 322,2 & 335,0 \\
\hline Lisina & 5,8 & 1,6 & 110,2 & 102,0 & 104,7 \\
\hline Histidina & 1,9 & 1,6 & 79,40 & 81,7 & 46,7 \\
\hline
\end{tabular}

Quadro 5 - Quantidade disponivel de aminoácidos em \% nas amostras de grão-de-bico cozido, nas doses de radiação 0,6 e 10kGy comparado com as necessidades de aminoácidos essenciais em humanos.

${ }^{1}$ Padrão FAO para humanos segundo suas necessidades

${ }^{2}$ Resultado representa os percentuais relativos de cada aminoácido ao valor de referência da FAO para pré-escolares

Comparando-se os grãos crus e cozido e a irradiação (Tabela 1 e 2), podemos observar que os melhores tratamentos para a composição de aminoácidos foram encontrados para o grão-de-bico cru irradiado a dose de $6 \mathrm{kGy}$, com exceção da metionina, seguido da dose de 10kGy. O mesmo não ocorreu para o grão-de-bico cozido que apresentou melhor composição de aminoácido a dose de $10 \mathrm{kGy}$, tendo como exceção a lisina e a histidina, seguido da dose de 0kGy.

Comparando-se os dados encontrados na Tabela 3, 4 e 5 podemos observar que o grão-de-bico cru apresentou estatisticamente uma melhor composição de aminoácidos, embora apresente valores próximos ao grão cozido, porém o grão-de-bico cru não é consumido na alimentação humana. 
A avaliação dos dados (Quadro 4 e 5), indicam que o aminoácido limitante para a maior parte dos tratamentos foi a metionina, com exceção do tratamento com $10 \mathrm{kGy}$ para o grão-de-bico cozido, o qual apresentou como limitante a histidina que apresentou o mais baixo percentual (46,7\%). O mesmo não ocorreu num estudo realizado por Tavano (2002) que encontrou como aminoácido limitante o triptofano, sendo que este apresentou o mais baixo percentual $(56,4 \%)$ em relação ao recomendado pela FAO.

Em relação aos aminoácidos essenciais o grão-de-bico apresentou um valor nutricional adequado, exceto para metionina e histidina. É importante ressaltar que para a alimentação de adultos e pré-escolares, a proteína do grão-de-bico, não apresentou limitação.

O aquecimento não causou prejuízos na composição de aminoácidos do grãode-bico. E embora a coç̧ão reduza os aminoácidos sulfurados de acordo com Adaway,(2000). Candela et al. (1997) não encontraram reduções dos teores de aminoácidos essenciais do grão-de-bico após cozimento dos mesmos, por fervura, durante 3 horas.

Clemente (1998) analisando a o perfil de aminoácido do grão-de-bico verificou que o único aminoácido que sofreu redução foi a arginina e cistina, quando submetida a aquecimento à $120^{\circ}$. C durante 50minutos. O mesmo ocorreu neste estudo embora o tempo de cocção tenha sido menor $121^{\circ}$.C durante 10 minutos.

Braga (1992) estudando a o perfil de aminoácido de diferentes cultuivares (IACIndia GB-3, IAC-India GB-4, IAC-Marrocos e IAC-México) do grão-de-bico verificou que estes apresentaram variação quanto ao conteúdo de aminoácidos, embora apresentem valores adequados, sendo que a metionina foi o aminoácido que mais variou entre as amostras analisadas. $O$ mesmo ocorreu no presente estudo.

Astiasaran (1997), observaram que para o grão-de-bico cozido a lisina foi o único aminoácido que sofreu redução com a cocção, já a lentilha teve redução de isoleucina, leucina, sendo mais afetada pela cocção. No presente estudo podemos observar que a cocção diminuiu a quantidade de valina, metionina, isoleucina leucina, fenilalanina, e histidina, embora apresentem valores valores de acordo com a literatura (Quadro 4 e 5) com exceção da metionina e histina.

De acordo com o Quadro 5 a proporção metionina/cistina apresentou valores abaixo do recomendado, embora com a irradiação essa proporção tenha aumentado 
55,$6 ; 73,0$ e $82,5 \%$ para as amostras a 0,6 e $10 \mathrm{kGy}$, mas sendo a metionina é o aminoácido sulfurado de maior interesse uma vez que na proporção metinina/cistina, a cisteína poderia requisitar a metionina como precursor, numa eventual necessidade de síntese no organismo (Reeds, 2000). 


\section{CONCLUSÕES}

Nas condições em que foi realizado o experimento pode-se concluir que:

- Na composição centesimal após a cocção só não houve alteração no teor de proteína e na composição mineral só se alterou o potássio;

- A melhor digestibilidade da proteína foi apresentada pelos grãos cozidos que receberam as maiores doses de radiação. O mesmo comportamento foi observado para a diálise de ferro;

- Os tratamentos não promoveram alterações nos teores de aminoácidos a ponto de ser importante para que seja instalada deficiência devido ao consumo do grãos.

Portanto a irradiação constitui-se em um método de conservação inócuo em relação à perda de nutrientes. É um método que deverá ser utilizado futuramente, pois seus custos não são onerosos quando comparados a outros métodos tradicionais. 


\section{REFERENCIAS BIBLIOGRAFICAS}

AGÊNCIA NACIONAL DE VIGILÂNCIA SANITÁRIA (ANVISA). Sistema de legislação em vigilância sanitária. http://www.anvisa.com.br (04 jul. 2004)

ADAWY, A.T.E. Nutritional composition and antinutritional factors of chickpeas (Cicer arietinum $\mathrm{L}$ ) undergoing diferrent cookin methods and germanation. Plant Food for Human Nutrition, v.57, n.1, p.83-97, 2002.

AHMED, M. Up-to-date status of food irradiation. Radiation Physics Chemistry, v.42, p.245-251, 1993.

AKESON, W.R.; STALMANN, M.A. A pepsina pancreatina digest index of protein quality evaluation. Journal Nutrition, v.83, p.257-261, 1964.

ALMEIDA, L.D. Comportamento de sementes de grão-de-bico na armazenagem. Bragantina, v.56, n.1, p.97-102, 1997.

ARMELIN, J.M. Efeito da irradiação gama na capacidade de hidratação e cocção de feijão comum (Phaseolus vulgaris L.). Agropecuária; resumos. São Paulo: USP, 2003. 310p.

ASSOCIATION OF OFFICIAL ANALYTICAL CHEMISTS (AOAC). Official methods of analysis. 16.ed. Washington, 1995. v.2, cap. 32, p.22-23: Cereal foods. 
ASTIASARAN, I.; CANDELA, M.; BELLO, J. Cooking and warm-holding: effect on genetal composition and amino acids of kidney beans (Phaseolus vulgaris), chickpeas (Cicer arietinum), and lentils (Lens culinaris). Journal Food Chemisty, v.45, n.12, p.4763-4767, 1997.

AVANCINI, S.R.; SALES, A.M.; AGUIRRE, J.M.; MANTOVANI, D.M.B. Composição química e valor nutricional de cultivares de grão-de-bico produzidos nos Estados de S.P. Coletânea do Instituto de Tecnologia de Alimentos, v.22, n.2, p.145-53, jul./dez. 1992.

BOCCIA, G.L.; LULLO, G.; CARNOVALE, E. In vitro dialysability from legumes: influence of phytate and extrusios cooking. Journal Science Food Agriculture, v.55, n.1, p.599-605, 1991.

BRAGA, N.R. Possibilidades da cultura do grão-de-bico (Cicer arietinum L.) na microregião de Viçosa, Minas Gerais: competição entre cultivares e nutrição mineral. Viçosa, 1997. 101p. Tese (Doutorado) - Universidade Federal de Viçosa.

BRAGA, N.R.; VIEIRA, R.F.; RAMOS, J.A.O. A cultura do grão-de-bico. Informe Agropecuário, v.16, n.174, p.47-52, 1992.

BRAGA, N.R.; VIEIRA, C. Efeito da inoculação com Bradyrhizobium sp, nitrogênio e micrornutrientes no rendimento do grão-de-bico. Bragantina, v.57, n.2, p.349-353, 1998.

BRIGIDE, P. Disponibilidade de ferro em grãos de feijão comum (Phaseolus vulgaris L.) irradiados. Piracicaba, 2002. 71p. Dissertação (Mestrado) - Escola Superior de Agricultura "Luiz de Queiroz", Universidade de São Paulo.

CANNIATTI-BRAZACA, S.G.; SILVA, F.C. da. Enchancers and inibitors of iron availability in legumes. Plant Food for Human Nutrition, v.58, p.1-8, 2004. 
CENTRO DE ENERGIA NUCLEAR NA AGRICULTURA (CENA). Irradiação de alimentos. http://www.cena.usp.br. (12 jul. 2003)

CHAVAN, J.K.; KADAN, S.S.; SALUNKHE, D.K. Biochemistry and technology chickpea (Cicer arietinum) seeds. Food Sciencies and Nutrition, v.25, p.107-58, 1988.

CHITRA, U.; SINGH, U.; RAO, P.V. Phytic acid, in vitro protein digestibility, dietary fiber and minerals of pulses as influienced by processing methods. Plant Foods Human Nutrition, v.49, p.307-316, 1996.

CHITRA, U.; SINGH, U.; RAO, P.V. Effect of varieties and processing methods on the total and ionizable iron contests of grain legumes. Journal of Agriculture Food Chemistry, v.45, n.10, p.3859-3862, 1997.

CLEMENTE, A. Effect of cooking on protein quality of chicckpea (Cicer arietinum) seeds. Food Chemistry, v.62, n.1,p.1-6, 1998.

DILAWARI, J.B. Reducion of postprandial plasma glucose by Bengal gram dhal (Cicer arietinum) and Rajmah (Phaseulus vultgaris). American Journal Clinical Nutricional, v.34, p.2450-03, 1981.

DODOK, L. Importance and utilization of chickpea in cereal technology. Acta Aliment., v. 22, n.2, p.119-29, 1993.

EMPRESA BRASILEIRA DE RADIAÇÃO (EMBRARAD). Alimentos. http://www.embrarad.com.br (12 jul. 2002)

FAO YEARBOOK TRADE. Roma, 2001. 300p.

FAO; INTERNATIONAL ATOMIC ENERGY AGENCY (IAEA); WORLD HEALTH ORGANIZATION FOOD SAFETY UNIT (WHO); INTERNATIONAL CONSULTIVE GROUP ON FOOD IRRADIATION (ICGFI). Code of good irradiation practice for insect desinfestation of died fruits and tree nuts. 1994, ICGFI/XI/WP-10, doc.18. 
FRANCO, G. Tabela de composição química dos alimentos. 9.ed. São Paulo: Atheneu, 1997. 46p.

GERMANO, R.M. de A. Disponibilidade de ferro na presença do $\beta$-caroteno e os efeitos dos interferentes em combinações de alimentos. Piracicaba, 2002. 95p. Dissertação (Mestrado) - Escola Superior de Agricultura "Luiz de Queiroz", Universidade de São Paulo.

INTERNATIONAL CONSULTIVE GROUP ON FOOD IRRADIATION (ICGFI). Seminar on food irradiation. Vienna, 1999.

INSTITUTO BRASILEIRO DE GEOGRAFIA E ESTATÍSTICA (IBGE). Tabelas de composição de alimentos. 4.ed. Rio de Janeiro, 1996. 24-36p.

KHAN, M.A.; EGGUM, B.O. Effect of home and indultrial processing on protein quality of baby foods and breakfast cereals. Journal of the Science of Food and Agriculture, v.30, n.4, p.369-376, 1979.

KHOKAR, S.; CHANHAN, B. M. Effect of domestic processing and cooking on "in vitro" protein digestibility of north bean. Journal of Food Science, v. 51, p.1083-1085, 1986.

KIKUCHI, O.K. Efeittos de baixas doses de radiação gama Cobalto-60 sobre sementes de feijão carioca. Ciência e Cultura, v.39, n.7, p.12, jul. 1987.

LUTEN, J.; CREWS, H.; FLYNN, A.; et al. Interlaboratory trial on the determination of the in vitro dialysability from food. Journal of the Science of Food an Agriculture, v.72, n.4, p.415-424, 1996.

ORGANIZACIÓN DE LAS NACIONES UNIDAS PARA LA AGRICULTURA Y LA ALIMENTACIÓN (LATINFOODS). Tabla de composición de alimentos de América Latina. http://www.rlc.fao.or/bases/alimentos/defaut.htm (8 dez. 2000) 
LOWRY, O.H.; ROSEOUGH, N.J.; FARR, A.L.; RANDALL, R.J. Protein measurement with the folin fenol reagent. The Journal of Biological Chemistry, v.193, n.1, p.265-275, 1951.

MAESEN, L.J.G. Van der origin, history and taxonomy of chickpea. In: SAXEMA, M.C.; SINGH, K.B. (Ed.). The chickpea. Wallingford: C.A.B. International; Aleppo: The International Center for Agricultural Research in the Dry Areas, 1987. p.11-34.

MANCINI-FILHO, J. Efeitos das radiações gama sobre algumas características físicosquímicas e nutricionais de feijōes (Phaseolus vulgaris L.) armazenados. São Paulo. 1990. 100p. Tese (Doutorado) - Faculdade de Ciências Farmacêuticas, Universidade de São Paulo.

MARQUEZ, M.C.; FERNANDEZ, V.; ALONSO, R. Effect of dry heat on the in vitro" digestibility and tripsin inibitor activity of chickpea flour. International Journal of Science and Tecnology, v.33, p.527-532, 1998.

MOLINA, M.R.; FUENTE, G. de LA; BRESSANI, R. Interrelationships between storage, soaking time, cooking time, nutritive value and other characteristics of the black bean (Phaseolus vulgaris). Journal of Food Science, v.40, p.587-591, 1975.

MOORE, S.; STEIN, W. Chromatographic determination of amino acids by the use of automatic recording. Methods in Enzymology, v.6, n.1, p.819-831, 1963.

MONSOOR, M.A.; YUSUF, H.K.M. In Vitro protein digestibility of lathyrus pea (Lathrus sativus), lentil (Lens culinaris), and chickpea (Cicer arietinum). International Journal of Food Science and Technology, v.37, n.1, p.97-99, 2002.

MORENO, C.R.; CARRILLO, J.M.; RODELO, E.A.; ESPARZA, J.O. Influence of storage at high tamperature and high relative humidity on seed quality of chickpea (Cicer arietinum L.). Food Science Techonologyc International, v.6, n.2, p.473-482, 2000. 
MUEHLBAUER, F.L. Advances in the production of cool season legumes. America Journal of Alternative Agriculture, v.11, p.71-76, 1996.

ORNELLAS,L.H. Técnica dietética: seleção e preparo de alimentos. 6.ed. São Paulo: Atheneu, 1995. p.51-167.

PIMENTEL-GOMES, F. Curso de estatística experimental. 10.ed. São Paulo: Nobel, 1982. 468p.

PINN, A.B.R. Os efeitos das radiações gama sobre a disponibilidade do ferro em feijões (Phaseolus vulgaris L). São Paulo, 1992. 129p. Dissertação (Mestrado) - Faculdade de Ciências Farmacêuticas, Universidade de São Paulo.

QUEIROZ, K. S.; COSTA, G.E. A.; OLIVEIRA, A. C. Composição centesimal de grão de ervilha (Pisum sativum), feijão-comum (Phaseulus vulgaris), grão-de-bico (Cicer arietinum) e lentilha (Lens culinaris) crus e cozidos liofilizados. In: CONGRESSO BRASILEIRO DE CIÉNCIA E TECNOLOGIA DE ALIMENTOS, 18., Porto Alegre, 2002. Integração pesquisa indústria. /Resumo em CAB Abstracts on CD-ROM, 20021

REEDS, P.J. Dispensable and indispensable amino acids for humamans. Journal Nutritional, v.130, n.1, p.1835S-40S,2000.

ROSSI, M.; GERMONDARI, I.; CASINI, P. Comparison of chickpea cultivars: chemical composition, nutricional evalution and oligosaccharide content. Journal of Agricultural and Food Chemistry, v.32, n.4, p.811-814, 1984.

SARRUGE, J.R.; HAAG, H.P. Análises químicas em plantas. Piracicaba: ESALQ/USP, 1974. 56p.

SING, U.; JAMBUTANATHAN, R. Studies on desi and kabuli chickpea (Cicer arietinum L.) cultivars: level of protease inhinitors, level of polyphenolic compounds an "in vitro"protein digestibility. Journal Food of Science, v.46, p.1364-7, 1981. 
SPACKMAN, D.H.; STEIN, W.H.; MOORE, S. Automatic recording apparatus for use in the chromatography of amino acids. Analytical Chemistry, v.30, p.1.190-1.206, 1958.

SPIES, J.R. Colorimetric procedures for amino acids. Methods in Enzymology, v.3, p.468-471, 1957.

STATISTICAL ANALYSIS SYSTEM INSTITUTE. SAS/QC software: usage and reference. Version 6. 2.ed. Cary, 1996. 2v.

TAVANO, O.L. Avaliação nutricional de frações protéicas do grão-de-bico (Cicer arietinum L.) var. IAC- Marrocos: estudo "in vivo" e "in vitro". Araraquara, 2002. 94p. Dissertação (Mestrado) - Faculdade de Ciências Farmacêuticas, Universidade do Estado de São Paulo.

TOTAL dietary fiber assay kit. Sigma Technical Bulletim, n.TDFAB-3, p.1-4, 2000.

UNIVERSIDADE DE SÃO PAULO. Faculdade de Ciências Farmacêuticas. Tabela de composição de alimentos. http://www.fcf.usp.br (20 fev. 2001)

UNITED STATES OF AGRICULTURE AGRICULTURAL RESEARCH SERVICE (USDA). National nutriente database for standard reference release. http://www.nal.usda.gov/fnic/foodcomp (15 July 2004)

VILLAVICENCIO, A.L.C.H. Avaliação dos efeitos da radiação ionizante de ${ }^{60} \mathrm{Co} \mathrm{em}$ propriedades físicas, químicas e nutricionais dos feijōes Phaseolus vulgaris $L e$ Vigna unguiculata (L) Walp. São Paulo, 1998. 138p. Tese (Doutorado) - Faculdade de Ciências Farmacêuticas, Universidade de São Paulo. 